\title{
EL TRATAMIENTO JURÍDICO DEL GENOCIDIO EN MÉXICO*
}

\author{
Luis L. CóRdOVA ARELLANO**
}

RESUMEN: El autor analiza el tipo penal de genocidio en México, haciendo referencia tanto a la Convención sobre Genocidio como al Código Penal Federal mexicano. Además, analiza dos resoluciones emitidas por la Suprema Corte de Justicia de la Nación mexicana relacionadas a este tipo penal. El autor estudia su génesis desde el fin de la Primera Guerra Mundial hasta el surgimiento de la Corte Penal Internacional, sin olvidar comentar las razones por las cuales se excluyó a los grupos políticos como protegidos dentro del tipo penal de genocidio. Finalmente, como en México no existe el tipo penal de crimen de lesa humanidad, propone que el mismo se correlacione con el de genocidio.

ABSTRACT: The author analyzes the criminal type of genocide in Mexico doing reference to the Convention against Genocide and to the Federal Criminal Law of Mexico. Moreover, he analyzes two resolutions emitted by the Mexican Supreme Court of Justice related to this criminal type. The author studies its genesis since the end of the First World War until the apparition of the International Criminal Court not without commenting the reasons why the political groups were excluded from the protection of the criminal type of genocide. Finally as the criminal type of Crimes Against Humanity does not exist in Mexico, he proposes that it should be related to genocide.

RÉSUMÉ: L'auteur fait une étude du type pénale de génocide en faisant référence à l'Convention contre le Génocide et au Code Pénale Fédéral du Mexique. En plus, il analyse deux résolutions de la Cour Suprême de Justice de la Nation mexicaine liés à ce type pénal. L'auteur étudie sa genèse depuis la fin de la Premier Guerre Mondial jusqu'à l'apparition de la Cour Pénale Internationale, sans oublier les raisons pour lesquels les groups politiques on était exclue de la protection du type pénale de génocide. Finalement, en raison de l'inexistence du type pénale de crimes contre l'humanité au Mexique, il propos que il soit lié avec le génocide.

* Artículo recibido el 23 de junio de 2008 y aceptado para su publicación el 25 de agosto de 2008.

** Profesor de Derecho internacional en la Facultad de Derecho de la UNAM. 
SUMARIO: I. El genocidio en el orden jurídico mexicano. II. Características del delito de genocidio. III. Génesis del tipo penal de genocidio. IV. El caso Cavallo. V. El caso "Los Halcones". VI. Sujeción a proceso de Luis Echeverría por genocidio.

VII. Conclusiones.

\section{EL GENOCIDIO EN EL ORDEN JURÍDICO MEXICANO}

El artículo 149 bis del Código Penal Federal tipifica el delito de genocidio. El profesor Ángel Caamaño Uribe, profesor de Derecho constitucional, jubilado de la Facultad de Derecho de la UNAM, señala que durante el sexenio de Miguel de la Madrid hubo "necesidad" de negociar nuevos préstamos para el pago de los intereses de la deuda (no la deuda en sí). ${ }^{1}$ La banca internacional, a través del Fondo Monetario Internacional impuso algunas condiciones, entre las cuales se encontraba la reducción de la natalidad. ${ }^{2}$ Entonces, el gobierno federal comenzó una campaña de planeación familiar ("menos hijos para darles más", etcétera). El profesor Caamaño Uribe argumenta que el gobierno federal buscó reducir la natalidad a "la de a fuerzas". Por eso promovió una reforma a la Ley General de Salud, a su artículo 67. Este artículo expresaba: "La planificación familiar, principalmente la que se dirija a menores y adolescentes, tiene carácter prioritario...". El segundo párrafo señalaba: "Quienes practiquen esterilización sin la voluntad de la paciente o ejerzan presión para que ésta la admita, serán sancionados conforme...",3 etcétera. Como el ar-

1 Caamaño Uribe, Ángel, "El artículo 67 de la Ley General de Salud y el delito de genocidio", Revista de la Facultad de Derecho de México, México, t. XXXIX, núms. 166-168, julio-diciembre de 1989.

2 Idem.

3 Idem; el artículo 67 actual (2006) de la Ley General de Salud establece lo siguiente: "La planificación familiar tiene carácter prioritario. En sus actividades se debe incluir la información y orientación educativa para los adolescentes y jóvenes. Asimismo, para disminuir el riesgo reproductivo, se debe informar a la mujer y al hombre sobre la inconveniencia del embarazo antes de los 20 años o bien después de los 35, así como la conveniencia de espaciar los embarazos y reducir su número; todo ello, mediante una correcta información anticonceptiva, la cual debe ser oportuna, eficaz y completa a la pareja. Los servicios que se presten en la materia constituyen un medio para el ejercicio del derecho de toda persona a decidir de manera libre, responsable e informada sobre el número y espaciamiento de los hijos, con pleno respeto a su dignidad. Quienes practiquen esterilización sin la voluntad del paciente o ejerzan presión para que éste la admita serán 
tículo antedicho dice "la paciente", entendido a contrario sensu - explica Caamaño - implica que podrá practicarse (legalmente) esterilización a menores adolescentes varones sin su voluntad. El profesor Caamaño considera esta medida como violatoria de la Convención para la Prevención y la Sanción del Delito de Genocidio (Convención de Genocidio), ${ }^{4}$ delito que es tan viejo como la humanidad, pero que se tipificó después de la Segunda Guerra Mundial (SGM). ${ }^{5}$ El delito de genocidio contiene el dolo específico de destruir a un grupo nacional, étnico, racial o religioso como tal. Puede ser cometido en tiempo de paz o de guerra. El profesor Caamaño considera que lo ocurrido el 2 de octubre de 1968 en Tlatelolco y el 10 de junio de 1971 en Tlaxpana tipifican crimen contra la humanidad, el cual si es cometido en tiempo de guerra sería crimen de guerra, y si se comente contra los propios súbditos del Estado tipifica crimen contra la humanidad. El 20 de enero de 1967 fue publicado en el Diario Oficial de la Federación (DOF) el decreto del 19 de noviembre de 1966, por el que se incorpora al Código Penal Federal (CPF) mexicano el delito de genocidio. ${ }^{6}$ Dicho delito se encuentra en el título tercero,

sancionados conforme a las disposiciones de esta Ley, independientemente de la responsabilidad penal en que incurran. En materia de planificación familiar, las acciones de información y orientación educativa en las comunidades indígenas deberán llevarse a cabo en español y en la lengua o lenguas indígenas en uso en la región o comunidad de que se trate". http://www.diputados.gob.mx/LeyesBiblio/index.htm, consultado en junio de 2008.

4 Firmada por México el 14 de diciembre de 1948, seis días después de haber sido adoptada por la Asamblea General de las Naciones Unidas el 9 de diciembre de 1948, aprobada por el Senado de la República el 29 de diciembre de 1951, publicada en el Diario Oficial de la Federación el 11 de octubre de 1962 y en vigor para México el 22 de octubre de 1952. Véase, http://www.sre.gob.mx/tratados/busqueda.htm y el texto en http://www.sre.gob.mx/derechoshumanos/docs/55.pdf.

5 Caamaño Uribe, Ángel, op. cit., nota 1, pp. 55 y 56. “... jamás en la antigüedad se tipificaron como delito los hechos constitutivos del genocidio. Ello se vino a hacer hasta el término de la Segunda Guerra Mundial. El jurista polaco Rápale Lemkin configura por primera vez en 1944 el delito de genocidio en la obra Axis Rule in Ocupied Europa publicada en Washington en el año citado. El crimen de genocidio - según Lemkin- es un crimen especial consistente en destruir intencionalmente grupos humanos, raciales, religiosos o nacionales y, como el homicidio singular, puede ser cometido tanto en tiempos de paz como en tiempo de guerra. En territorio ocupado por el enemigo y el tiempo de guerra será denominado crímenes de guerra y si en la misma ocasión se comete contra los propios súbditos (del Estado en cuestión), será denominado crímenes contra la humanidad. El crimen de genocidio se halla compuesto de varios actos subordinados todos al dolo específico de destruir un grupo humano".

6 Caamaño Uribe, Ángel, op. cit., nota 1. 
de los "Delitos contra la humanidad", en el Código Penal Federal, título en el cual se encuentran: 1. la violación de los deberes de humanidad en los prisioneros y rehenes de guerra y 2. el genocidio. No contempla el tipo penal de "crímenes contra la humanidad" (o también crimen de lesa humanidad). ${ }^{7}$

La redacción del artículo 149 bis del CPF tiene como antecedente, claramente, la Convención de Genocidio; y en el primer parráfo establece que "comete el delito de genocidio el que con el propósito de destruir, total o parcialmente a uno o más grupos nacionales o de carácter étnico, racial o religioso, perpetrase por cualquier medio, delitos contra la vida de miembros de aquellos, o impusiese la esterilización masiva con el fin de impedir la reproducción del grupo". El CPF mexicano hace referencia explícita a la esterilización forzosa, y la Convención de Genocidio, en su artículo II d) tipifica las conductas "destinadas a impedir los nacimientos en el seno del grupo", y cometidas con la intención de destruir total o parcialmente a un grupo nacional, étnico, racial o religioso. ${ }^{8}$ Estas medi-

7 Código Penal Federal, http://www.diputados.gob.mx/LeyesBiblio/pdf/9.pdf, consultado en junio de 2008: "Artículo 149 bis. Comete el delito de genocidio el que con el propósito de destruir, total o parcialmente a uno o más grupos nacionales o de carácter étnico, racial o religioso, perpetrase por cualquier medio, delitos contra la vida de miembros de aquellos, o impusiese la esterilización masiva con el fin de impedir la reproducción del grupo. Por tal delito se impondrán de veinte a cuarenta años de prisión y multa de quince mil a veinte mil pesos. Si con idéntico propósito se llevaren a cabo ataques a la integridad corporal o a la salud de los miembros de dichas comunidades o se trasladaren de ellas a otros grupos menores de diez y seis años, empleando para ello la violencia física o moral, la sanción será de cinco a veinte años de prisión y multa de dos mil a siete mil pesos. Se aplicarán las mismas sanciones señaladas en el párrafo anterior, a quien con igual propósito someta intencionalmente al grupo a condiciones de existencia que hayan de acarrear su destrucción física, total o parcial. En caso de que los responsables de dichos delitos fueran gobernantes, funcionarios o empleados públicos y las cometieren en ejercicio de sus funciones o con motivo de ellas, además de las sanciones establecidas en este artículo se les aplicarán las penas señaladas en el artículo 15 de la Ley de Responsabilidades de los Funcionarios y Empleados de la Federación".

8 Convención para la Prevención y Sanción del Delito de Genocidio, artículo I. Las partes contratantes confirman que el genocidio, ya sea cometido en tiempo de paz o en tiempo de guerra, es un delito de derecho internacional que ellas se comprometen a prevenir y a sancionar. artículo II. En la presente Convención, se entiende por genocidio cualquiera de los actos mencionados a continuación, perpetrados con la intención de destruir, total o parcialmente, a un grupo nacional, étnico, racial o religioso, como tal: a) Matanza de miembros del grupo; b) Lesión grave a la integridad física o mental de los miembros del grupo; c) Sometimiento intencional del grupo a condiciones de existencia 
das pueden implicar la esterilización forzosa, el aborto forzoso, la segregación de sexos, o la prohibición de matrimonios. ${ }^{9}$ Además, dicho artículo tipifica como genocidio los siguientes actos: 1. la intención de destruir grupos nacionales, o de carácter étnico, racial o religioso (prisión de 20 a 40 años y multa de 15 mil a 20 mil pesos); 2. delitos contra la vida de los grupos protegidos con la intención de destruir grupos nacionales, o de carácter étnico, racial o religioso (prisión de 20 a 40 años y multa de 15 mil a 20 mil pesos); 3. la esterilización masiva a fin de impedir la reproducción del grupo ("prototipo del genocidio biológico"; ${ }^{10}$ prisión de 20 a 40 años y multa de 15 mil a 20 mil pesos); 4. ataques contra la integridad corporal o la salud de los miembros de las comunidades, mediante violencia física o moral (prisión de 5 a 20 años; multa de 2 mil a 7 mil pesos); 5. traslado de menores de 16 años a miembros de las comunidades hacia otros grupos mediante violencia física o moral (prisión de 5 a 20 años; multa de 2 mil a 7 mil pesos); 6 . el sometimiento intencional del grupo (nacional, étnico, racial o religioso) a condiciones de existencia que hayan de acarrear su destrucción física, total o parcialmente (prisión de 5 a 20 años; multa de 2 mil a 7 mil pesos); 7. existe una estipulación específica, respecto a que el delito sea cometido por gobernantes, funcionarios o empleados públicos. La redacción de este artículo se debe al ex rector de la UNAM, Luis Garrido. ${ }^{11}$

El profesor Caamaño cuestiona que el citado artículo no distinga entre étnico y racial, y que no se especifique qué cantidad de gente debe considerarse "masiva esterilización" de grupos de personas. Considera que lo étnico es racial y lo racial es étnico, pero no abunda en argumentos. Por otra parte, el profesor Caamaño señala que la Convención sobre la Imprescriptibilidad de los Crímenes de Guerra y de los Crímenes de

que hayan de acarrear su destrucción física, total o parcial; d) Medidas destinadas a impedir los nacimientos en el seno del grupo; e) Traslado por fuerza de niños del grupo a otro grupo.

9 Gil Gil, Alicia, "Los crímenes contra la humanidad y el genocidio en el Estatuto de la Corte Penal Internacional a la luz de "los elementos de los crímenes"”, en Kai Ambos (coord.), La nueva justicia penal supranacional, desarrollo post-Roma, Valencia, España, Tirant lo Blanch, 2001, pp. 102-103.

10 Ibidem, p. 102.

11 Caamaño Uribe, Ángel, op. cit., nota 1, p. 56. Luis Garrido, rector de la UNAM del 2 de junio de 1948 al 2 de junio de 1952, y del 2 de junio de 1952 al 14 de febrero de 1953, véase http://www.unam.mx/acercaunam/unam_tiempo/rectores/rectores3.html. 
Lesa Humanidad ${ }^{12}$ (Convención sobre Imprescriptibilidad) determina que los crímenes contra la humanidad y el genocidio son imprescriptibles. Esta Convención fue adoptada por la Asamblea General de la ONU el 26 de noviembre de 1968, y entró en vigor el 11 de noviembre de 1970. México la firmó ad referéndum, el 3 de julio de 1969. El 10 de diciembre de 2001 fue ratificada por el Senado de la República conforme a su facultad discrecional del artículo 76, fracción I, de la Constitución Política de los Estados Unidos Mexicanos, realizando una declaración interpretativa. Dicha declaración interpretativa señala que "se entenderá que únicamente considerará imprescriptibles los crímenes que consagra la Convención, cometidos con posterioridad a su entrada en vigor para México". ${ }^{13}$ El profesor Caamaño explica que los senadores confunden irretroactividad con imprescriptibilidad, ya que el Constituyente mexicano reservó al legislador ordinario la cuestión de la prescriptibilidad o imprescriptibilidad. ${ }^{14}$ Esta "declaración interpretativa" hecha por el Senado mexicano es, más bien, una reserva, la cual resulta nula porque no respeta el propósito y fin de la Convención sobre Imprescriptibilidad, el cual es — valga la redundancia - reconocer como imprescriptibles los crímenes de gue-

12 Firmada por México el 3 de junio de 1969, aprobada por el Senado de la República el 10 de diciembre de 2001, publicada en Diario Oficial de la Federación el 16 de enero de 2002 y fe de erratas el 11 de febrero de 2002, entrando en vigor para México el 13 de junio de 2003. Véase, http://www.sre.gob.mx/derechoshumanos/docs/56.pdf, consultada en junio de 2008. Al ratificar la Convención, el Gobierno de México formuló la declaración interpretativa siguiente: "Con fundamento en el artículo 14 de la Constitución Política de los Estados Unidos Mexicanos, el Gobierno de México, al ratificar la Convención sobre la Imprescriptibilidad de los Crímenes de Guerra y de los Crímenes de Lesa Humanidad, adoptada por la Asamblea General de las Naciones Unidas el 26 de noviembre de 1968, entenderá que únicamente considerará imprescriptibles los crímenes que consagra la Convención, cometidos con posterioridad a su entrada en vigor para México". Hablaremos más delante de esta "declaración interpretativa".

13 Analizaremos esta declaración interpretativa más adelante en el apartado sobre el caso Los halcones.

14 Caamaño Uribe, Ángel, op. cit., nota 1, p. 58. "Pero da la casualidad de que ni el artículo 14 ni ningún otro precepto de nuestra carta magna se refiere a la prescriptibilidad o imprescriptibilidad de los delitos, por la sencilla razón de que el constituyente reservó esta cuestión al legislador ordinario. El artículo 14 constitucional se refiere a la irretroactividad de las leyes, lo cual nada tiene que ver con la imprescriptibilidad de los delitos. Sea como fuere, la Convención Internacional que declara imprescriptibles los crímenes contra la humanidad y los crímenes de guerra, entró en vigor el día 11 de noviembre de 1970 y en la actualidad está vigente (¿o no, señor Klaus Barbie?)”. 
rra, las infracciones graves enumeradas en las convenciones de Ginebra de 1949, los crímenes de lesa humanidad, el apartheid y el genocidio. ${ }^{15}$

El tipo penal de genocidio del artículo 149 bis del CPF mexicano sanciona tanto el genocidio físico ${ }^{16}$ como biológico. ${ }^{17} \mathrm{Al}$ igual que la Convención de Genocidio, protege a grupos de carácter nacional, étnico, racial o religioso. A diferencia de la Convención de Genocidio, el CPF mexicano utiliza el término "comunidades". El CPF mexicano determina que el genocidio podría cometerse por acción u omisión (artículo 7o. y ss.). Tipifica, también, la tentativa de genocidio (artículo 12 y ss.); determina las personas responsables de genocidio (artículo 13); ${ }^{18}$ determina al genocidio como delito grave (artículo 194). ${ }^{19}$

Por otra parte, los siguientes instrumentos nacionales e internacionales vigentes, obligatorios para México, se refieren al genocidio: 1. Convención para la Prevención y la Sanción del Delito de Genocidio, Nueva York, 9 de diciembre de 1948, ratificación por México: 22 de julio de

15 Becerra Ramírez, Manuel, "Genocidio a) Comentarios sobre la sentencia de la Suprema Corte de Justicia de la Nación en el caso de 'Los Halcones'”, Cuestiones Constitucionales, México, núm. 14, enero-junio de 2006.

16 Representan genocidio físico los siguientes actos: 1. la matanza de miembros del grupo como tal (nacional, étnico, racial o religioso); 2. la lesión grave a la integridad física o mental de los miembros del grupo; y 3. el sometimiento intencional del grupo a condiciones de existencia que hayan de acarrear su destrucción física, total o parcial.

17 Se refiere al impedimento de nacimientos en el seno de un grupo y/o el traslado por la fuerza de niños del grupo a otro grupo, así como al traslado por fuerza de niños del grupo a otro grupo.

18 Código Penal Federal, artículo 13. Son autores o partícipes del delito: I. Los que acuerden o preparen su realización. II. Los que los realicen por sí; III. Los que lo realicen conjuntamente; IV. Los que lo lleven a cabo sirviéndose de otro; V. Los que determinen dolosamente a otro a cometerlo; VI. Los que dolosamente presten ayuda o auxilien a otro para su comisión; VII. Los que con posterioridad a su ejecución auxilien al delincuente, en cumplimiento de una promesa anterior al delito y VIII. los que sin acuerdo previo, intervengan con otros en su comisión, cuando no se pueda precisar el resultado que cada quien produjo. Los autores o partícipes a que se refiere el presente artículo responderán cada uno en la medida de su propia culpabilidad. Para los sujetos a que se refieren las fracciones VI, VII y VIII, se aplicará la punibilidad dispuesta por el artículo 64 bis de este Código.

19 Código Federal de Procedimientos Penales, http://www.diputados.gob.mx/LeyesBiblio/pdf/7.pdf, consultado en junio de 2008, "Artículo 194. Se califican como delitos graves, para todos los efectos legales, por afectar de manera importante valores fundamentales de la sociedad, los previstos en los ordenamientos legales siguientes: .. 8) Genocidio, previsto en el artículo 149 bis". 
1952, Decreto Promulgatorio, DOF, 11 de octubre de 1952. 2. Pacto Internacional de Derechos Civiles y Políticos, Nueva York, 16 de diciembre de 1966, adhesión de México: 24 de marzo de 1981, Decreto Promulgatorio, DOF, 20 de mayo de 1981, Fe de Erratas, DOF, 22 de junio de 1981. ${ }^{20}$ 3. Decreto de Promulgación del Estatuto de Roma de la Corte Penal Internacional, adoptado en la ciudad de Roma, el 17 de julio de 1998. DOF, 31 de diciembre de 2005.21 4. Convención Sobre la Imprescriptibilidad de los Crímenes de Guerra y de los Crímenes de Lesa

20 Pacto Internacional de Derechos Civiles y Políticos, http://www.sre.gob.mx/dere choshumanos/docs/13.pdf, consultado en junio de 2008: Artículo 6. 1. El derecho a la vida es inherente a la persona humana. Este derecho estará protegido por la ley. Nadie podrá ser privado de la vida arbitrariamente. 2. En los países que no hayan abolido la pena capital sólo podrá imponerse la pena de muerte por los más graves delitos y de conformidad con leyes que estén en vigor en el momento de cometerse el delito y que no sean contrarias a las disposiciones del presente pacto ni a la Convención para la protección y la sanción del delito de genocidio. Esta pena sólo podrá imponerse en cumplimiento de sentencia definitiva de un tribunal competente. 3. Cuando la privación de la vida constituya delito de genocidio se tendrá entendido que nada de lo dispuesto en este artículo excusará en modo alguno a los Estados partes del cumplimiento de ninguna de las obligaciones asumidas en virtud de las disposiciones de la Convención para la prevención y la sanción del delito de genocidio.

21 Decreto de Promulgación del Estatuto de Roma de la Corte Penal Internacional, adoptado en la ciudad de Roma, el diecisiete de julio de mil novecientos noventa y ocho, http://www.ordenjuridico.gob.mx/JurInt/31122005.pdf, consultado en junio de 2008. Vicente Fox QuesadA, PRESIDENTE DE LOS Estados Unidos MEXICANOS, a sus habitantes, sabed: El siete de septiembre de dos mil, el Plenipotenciario de los Estados Unidos Mexicanos, debidamente autorizado para tal efecto, firmó ad referéndum el Estatuto de Roma de la Corte Penal Internacional, adoptado en Roma el diecisiete de julio de mil novecientos noventa y ocho. El Estatuto mencionado fue aprobado por la Cámara de Senadores del Honorable Congreso de la Unión, el veintiuno de junio de dos mil cinco, según decreto publicado en el Diario Oficial de la Federación del siete de septiembre del propio año. El instrumento de ratificación, firmado por el Ejecutivo Federal a mi cargo el diez de octubre de dos mil cinco, fue depositado en poder del secretario general de las Naciones Unidas el veintiocho del propio mes y año, de conformidad con lo dispuesto en el artículo 125 (2) del Estatuto de Roma de la Corte Penal Internacional. Por lo tanto, para su debida observancia, en cumplimiento de lo dispuesto en la fracción I del artículo 89 de la Constitución Política de los Estados Unidos Mexicanos, promulgo el presente Decreto, en la residencia del Poder Ejecutivo Federal, en la ciudad de México, Distrito Federal, el cinco de diciembre de dos mil cinco. Transitorio. Único. El presente Decreto entrará en vigor el primero de enero de dos mil seis. 
Humanidad, DOF, 22 de abril de 2002.22 5. Declaración Sobre la Raza y los Prejuicios Raciales, adopción: Organización de las Naciones Unidas para la Educación, la Ciencia y la Cultura (UNESCO), 27 de noviembre de 1978.23 6. Declaración sobre los Derechos de las Personas Pertene-

22 Convención sobre la Imprescriptibilidad de los Crímenes de Guerra y de los Crímenes de Lesa Humanidad, Diario Oficial de la Federación 22 de abril de 2002, http:// www.ordenjuridico.gob.mx/TratInt/Penal/OE21.pdf, consultada en junio de 2008. VICENTE Fox Quesada, PREsidente De Los Estados Unidos Mexicanos, a sus habitantes, sabed: El tres de julio de mil novecientos sesenta y nueve, el Plenipotenciario de los Estados Unidos Mexicanos, debidamente autorizado para tal efecto, firmó ad referéndum la Convención sobre la Imprescriptibilidad de los Crímenes de Guerra y de los Crímenes de Lesa Humanidad, adoptada por la Asamblea General de las Naciones Unidas el veintiséis de noviembre de mil novecientos sesenta y ocho, cuyo texto en español consta en la copia certificada adjunta. La Convención mencionada fue enviada a la consideración de la Cámara de Senadores del honorable Congreso de la Unión, con la Declaración Interpretativa que a continuación se detalla, siendo aprobada por dicha Cámara el diez de diciembre de dos mil uno, según decreto publicado en el Diario Oficial de la Federación del dieciséis de enero de dos mil dos y la Fe de erratas publicada en el Diario Oficial de la Federación del once de febrero del propio año... Artículo I. Los crímenes siguientes son imprescriptibles, cualquiera que sea la fecha en que se hayan cometido: a) los crímenes de guerra según la definición dada en el Estatuto del Tribunal Militar Internacional de Nüremberg, de 8 de agosto de 1945, y confirmada por las resoluciones de la Asamblea General de las Naciones Unidas 3 (I) del 13 de febrero de 1946 y 95 (I) del 11 de diciembre de 1946, sobre todo las "infracciones graves" enumeradas en los Convenios de Ginebra del 12 de agosto de 1949 para la protección de las víctimas de la guerra; b) los crímenes de lesa humanidad cometidos tanto en tiempo de guerra como en tiempo de paz, según la definición dada en el Estatuto del Tribunal Militar Internacional de Nüremberg, del 8 de agosto de 1945 y confirmada por las resoluciones de la Asamblea General de las Naciones Unidas 3 (I) del 13 de febrero de 1946 y 95 (I) del 11 de diciembre de 1946, así como la expulsión por ataque armado u ocupación y los actos inhumanos debidos a la política de apartheid y el delito de genocidio definido en la Convención de 1948 para la prevención y la sanción del delito de genocidio aun si esos actos no constituyen una violación del derecho interno del país donde fueron cometidos.

23 Declaración sobre la Raza y los Prejuicios Raciales, adopción: Organización de las Naciones Unidas para la Educación, la Ciencia y la Cultura (UNESCO), 27 de noviembre de 1978, http://www.ordenjuridico.gob.mx/TratInt/Derechos\%20Humanos/INST \%2023.pdf, consultada en junio de 2008. Tomando nota de la Convención internacional para la prevención y la sanción del delito de genocidio, la Convención internacional sobre la represión y el castigo del crimen de apartheid y la Convención sobre la imprescriptibilidad de los crímenes de guerra y de los crímenes de lesa humanidad... Artículo 4... 2. El apartheid es una de las violaciones más graves de ese principio y, como el genocidio, constituye un crimen contra la humanidad que perturba gravemente la paz y la seguridad internacionales.... Artículo 10. Se invita a las organizaciones internacionales, universales y regionales, gubernamentales y no gubernamentales, a que presten su coope- 
cientes a Minorías Nacionales o Étnicas, Religiosas y Lingüísticas, adopción: Asamblea General de la ONU, Resolución 47/135, 18 de diciembre de 1992.24 7. Convención Internacional sobre la Represión y el Castigo del Crimen de Apartheid, adopción: Nueva York, 30 de noviembre de 1973, adhesión de México: 4 de marzo de 1980, Decreto Promulgatorio DOF, 3 de abril de $1980 .{ }^{25}$ 8. Código de Conducta para Funcionarios Encargados de Hacer Cumplir la Ley, adopción: Asamblea General de la ONU, Resolución 34/169, 17 de diciembre de 1979. ${ }^{26}$ 9. Decreto de Pro-

ración y ayuda dentro de los límites de sus competencias respectivas y de sus medios, a la aplicación plena y entera de los principios enunciados en la presente Declaración, contribuyendo así a la lucha legítima de todos los seres humanos, nacidos iguales en dignidad y en derechos, contra la tiranía y la opresión del racismo, de la segregación racial, del apartheid y del genocidio, a fin de que todos los pueblos del mundo se libren para siempre de esos azotes.

24 Declaración sobre los Derechos de las Personas Pertenecientes a Minorías Nacionales o Étnicas, Religiosas y Lingüísticas, http://www.ordenjuridico.gob.mx/TratInt/De rechos\%20Humanos/INST\%2026.pdf, consultada en junio de 2008... Deseando promover la realización de los principios enunciados en la Carta, la Declaración Universal de Derechos Humanos, la Convención para la Prevención y la Sanción del Delito de Genocidio, la Convención Internacional sobre la Eliminación de todas las formas de Discriminación Racial, el Pacto Internacional de Derechos Civiles y Políticos, el Pacto Internacional de Derechos Económicos, Sociales y Culturales, la Declaración sobre la Eliminación de todas las Formas de Intolerancia y Discriminación Fundadas en la Religión o las Convicciones y la Convención sobre los Derechos del Niño, así como en otros instrumentos internacionales pertinentes aprobados a nivel mundial o regional y los celebrados entre distintos Estados miembros de las Naciones Unidas.

25 Convención Internacional sobre la Represión y el Castigo del Crimen de Apartheid, http://www.sre.gob.mx/derechoshumanos/docs/59.pdf, consultado en junio de 2008: ... Observando que en la Convención para la Prevención y la Sanción del Delito de Genocidio ciertos actos que pueden calificarse también de actos de apartheid constituyen un delito de derecho internacional.

26 Código de Conducta para Funcionarios Encargados de Hacer Cumplir la Ley, http://www.ordenjuridico.gob.mx/TratInt/Derechos\%20Humanos/OTROS\%2002.pdf, consultado en junio de 2008: ... Artículo 2o. En el desempeño de sus tareas, los funcionarios encargados de hacer cumplir la ley respetarán y protegerán la dignidad humana y mantendrán y defenderán los derechos humanos de todas las personas. Comentario: a) los derechos humanos de que se trata están determinados y protegidos por el derecho nacional y el internacional. Entre los instrumentos internacionales pertinentes están la Declaración Universal de Derechos Humanos, el Pacto Internacional de Derechos Civiles y Políticos, la Declaración sobre la Protección de todas las Personas contra la Tortura y otros Tratos o Penas Crueles, Inhumanos o Degradantes, la Declaración de las Naciones Unidas sobre la eliminación de todas las formas de discriminación racial, la Convención Internacional sobre la Eliminación de Todas las Formas de Discriminación Racial, la Convención 
mulgación del Tratado de Extradición entre los Estados Unidos Mexicanos y la República de Corea, DOF, 30 de enero de 1998.27 10. Declaración Universal sobre el Genoma Humano y los Derechos Humanos, adopción: Organización de las Naciones Unidas para la Educación, la Ciencia y la Cultura (UNESCO), 11 de noviembre de 1997. ${ }^{28} 11$. Ley de

Internacional sobre la Represión y el Castigo del Crimen de Apartheid, la Convención para la Prevención y la Sanción del Delito de Genocidio, las Reglas Mínimas para el Tratamiento de los Reclusos y la Convención de Viena sobre Relaciones Consulares.

27 Decreto de Promulgación del Tratado de Extradición entre los Estados Unidos Mexicanos y la República de Corea, http://www.ordenjuridico.gob.mx/TratInt/Penal/ COR.pdf, consultado en junio de 2008:... Artículo 3o. Negativa Obligatoria de Extradición. La extradición no será concedida conforme a este Tratado en ninguna de las siguientes circunstancias: 1 . Cuando la parte requerida determine que el delito por el que se solicita la extradición es un delito político o un delito relacionado con un delito político. La referencia a un delito político no incluirá los siguientes delitos: (a) la privación de la vida o su tentativa, o agresión a la persona de un jefe de Estado o jefe de Gobierno o miembro de su familia; (b) un delito respecto del cual las partes contratantes tienen obligación de establecer su jurisdicción o extraditar debido a un acuerdo multilateral del cual ambos Estados son parte; y (c) un delito en contra de las leyes relativas al genocidio, terrorismo o secuestro. 2. Cuando la persona requerida está siendo procesada contra o ha sido enjuiciada y absuelta o sentenciada en el territorio de la parte requerida por el delito por el cual la extradición es solicitada. 3. Cuando el procesamiento o la pena por el delito por el que se solicita la extradición fuera negado por las razones prescritas de conformidad con la ley de cada parte contratante, incluyendo una ley relativa a la prescripción.

28 Declaración Universal sobre el Genoma Humano y los Derechos Humanos, http://www.ordenjuridico.gob.mx/TratInt/Derechos\%20Humanos/INST\%2031.pdf, consultado en junio de 2008: Recordando solemnemente su adhesión a los principios universales de los derechos humanos afirmados, en particular, en la Declaración Universal de Derechos Humanos, del 10 de diciembre de 1948, y los dos pactos internacionales de las Naciones Unidas de Derechos Económicos, Sociales y Culturales y de Derechos Civiles y Políticos, del 16 de diciembre de 1966; la Convención de las Naciones Unidas para la Prevención y la Sanción del Delito de Genocidio, del 9 de diciembre de 1948; la Convención Internacional de las Naciones Unidas sobre la Eliminación de todas las Formas de Discriminación Racial, del 21 de diciembre de 1965; la Declaración de las Naciones Unidas de los Derechos del Retrasado Mental, del 20 de diciembre de 1971; la Declaración de las Naciones Unidas de los Derechos de los Impedidos, del 9 de diciembre de 1975, la Convención de las Naciones Unidas sobre la Eliminación de todas las Formas de Discriminación contra la Mujer, del 18 de diciembre de 1979; la Declaración de las Naciones Unidas sobre los Principios Fundamentales de Justicia para las Víctimas de Delitos y del Abuso de Poder, del 29 de noviembre de 1985; la Convención de las Naciones Unidas sobre los Derechos del Niño, del 20 de noviembre de 1989, las Normas Uniformes de las Naciones Unidas sobre la Igualdad de Oportunidades para las Personas con Discapacidad, del 20 de diciembre de 1993; la Convención sobre la Prohibición del Desarrollo, la 
Seguridad Nacional, DOF, 31 de enero de 2005. ${ }^{29}$ 12. Decreto Promulgatorio del Tratado de Asistencia Jurídica Mutua en Materia Penal entre los Estados Unidos Mexicanos y la República Portuguesa, firmado en la ciudad de Lisboa, el veinte de octubre de mil novecientos noventa y ocho, DOF, 4 de mayo de 2000. ${ }^{30}$ 13. Declaración y Programa de Acción de Viena, adopción: Conferencia Mundial de Derechos Humanos, Viena, Austria, 25 de junio de 1993. ${ }^{31}$

\section{CARACTERÍSTICAS DEL DELITO DE GENOCIDIO}

La Convención de Genocidio de 1948 define este tipo penal de la siguiente a manera:

Producción y el Almacenamiento de Armas Bacteriológicas (biológicas) y Toxínicas y sobre su Destrucción, del 16 de diciembre de 1971; la Convención de la UNESCO relativa a la Lucha contra las Discriminaciones en la Esfera de la Enseñanza, del 14 de diciembre de 1960; la Declaración de Principios de la Cooperación Cultural Internacional de la UNESCO, del 4 de noviembre de 1966; la Recomendación de la UNESCO relativa a la Situación de los Investigadores Científicos, del 20 de noviembre de 1974; la Declaración de la UNESCO sobre la Raza y los Prejuicios Raciales, del 27 de noviembre de 1978; el Convenio de la OIT (núm. 111) relativo a la Discriminación en Materia de Empleo y Ocupación, del 25 de junio de 1958, y el Convenio de la OIT (núm. 169) sobre Pueblos Indígenas y Tribales en Países Independientes, del 27 de junio de 1989...

29 Ley de Seguridad Nacional, http://www.ordenjuridico.gob.mx/Federal/PE/APF/ $A P C / S E G O B /$ Leyes/L-11.pdf, consultada en junio de 2008: "Artículo 5o. Para los efectos de la presente Ley, son amenazas a la Seguridad Nacional: I. Actos tendentes a consumar espionaje, sabotaje, terrorismo, rebelión, traición a la patria, genocidio, en contra de los Estados Unidos Mexicanos dentro del territorio nacional".

30 Decreto Promulgatorio del Tratado de Asistencia Jurídica Mutua en Materia Penal entre los Estados Unidos Mexicanos y la República Portuguesa, firmado en la ciudad de Lisboa, el veinte de octubre de mil novecientos noventa y ocho, http://www.ordenjuri dico.gob.mx/TratInt/Penal/AE10BIS.pdf, consultado en junio de 2008:... 8. Para los efectos de lo expuesto en el punto a) del numeral 1 no se consideran delitos de naturaleza política o conexas: “d) el genocidio, los crímenes de lesa humanidad, los crímenes de guerra y violaciones graves según las convenciones de Ginebra de 1949”.

31 Declaración y Programa de Acción de Viena, http://www.ordenjuridico.gob.mx/ TratInt/Derechos\%20Humanos/INST\%2033.pdf, consultada en junio de 2008, "28. La Conferencia Mundial de Derechos Humanos expresa su consternación ante las violaciones masivas de los derechos humanos, especialmente el genocidio, la "limpieza étnica" y la violación sistemática de mujeres en situaciones de guerra, lo que da lugar al éxodo en masa de refugiados y personas desplazadas. Condena firmemente esas prácticas odiosas y reitera su llamamiento para que se castigue a los autores de esos crímenes y se ponga fin inmediatamente a esas prácticas". 
Artículo 6. Genocidio

A los efectos del presente Estatuto, se entenderá por "genocidio" cualquiera de los actos mencionados a continuación, perpetrados con la intención de destruir total o parcialmente a un grupo nacional, étnico, racial o religioso como tal:

a) Matanza de miembros del grupo;

b) Lesión grave a la integridad física o mental de los miembros del grupo;

c) Sometimiento intencional del grupo a condiciones de existencia que hayan de acarrear su destrucción física, total o parcial;

d) Medidas destinadas a impedir nacimientos en el seno del grupo;

e) Traslado por la fuerza de niños del grupo a otro grupo.

En esta Convención encontramos dos tipos de genocidio: el físico y el biológico. El llamado "genocidio cultural" (destrucción del lenguaje, su cultura, tradiciones o religión de miembros de un grupo nacional, étnico, racial o religioso) fue excluido de la Convención de Genocidio. ${ }^{32} \mathrm{Re}-$ presentan genocidio físico los siguientes actos: 1. la matanza de miembros del grupo como tal (nacional, étnico, racial o religioso); 2. la lesión grave a la integridad física o mental de los miembros del grupo; y 3. el sometimiento intencional del grupo a condiciones de existencia que hayan de acarrear su destrucción física, total o parcial. El genocidio biológico se refiere al impedimento de nacimientos en el seno de un grupo y/o el traslado por la fuerza de niños del grupo a otro grupo, así como el traslado por fuerza de niños del grupo a otro grupo. Los elementos del tipo del delito de genocidio son la intención, el concepto de grupo y su lesión. El móvil, el cual puede ser de carácter político, económico, xenófobo o la simple venganza, es irrelevante para la existencia del genocidio. ${ }^{33} \mathrm{Si}$ los móviles se incluían en el tipo penal de genocidio, después podría alegarse como defensa un móvil distinto del que se acusa. Debido a eso se omite el móvil dentro de los elementos del tipo penal de genocidio.

32 El "genocidio cultural" es muy similar al denominado delito de "vandalismo" propuesto por Lemkin. Chomsky, Noam, El nuevo humanismo militar, lecciones de Kosovo, trad. de Bertha de la Concha Ruiz, México, Siglo XXI, 2002, p. 66. Este autor señala que "desde hace años, la represión turca de los kurdos ha sido un escándalo, incluso se ha llegado a penalizar el uso del idioma kurdo o la mención de la identidad kurda".

33 Gil Gil, Alicia, op. cit., nota 9, p. 95. "El móvil con el que se actúe es irrelevante para la existencia del delito. Se puede actuar con el propósito de destruir el grupo por motivos políticos, económicos, xenófobos, por venganza”. 
Por otra parte, para la consumación del delito de genocidio no es necesaria la efectiva destrucción del grupo protegido como tal (nacional, étnico, racial o religioso), basta la intención de destruir a dicho grupo. ${ }^{34}$ Lo que se protege con el tipo penal es la existencia de ciertos grupos como tales (nacional, étnico, racial o religioso). Se considera que protegiendo a estos grupos, se está protegiendo de alguna manera a la humanidad. Por lo tanto, el titular del bien jurídico es el grupo protegido como tal, como colectividad, y cada uno de los miembros está protegido por su identidad con el grupo. Bastaría una sola muerte con la intención de destruir a un grupo para que el delito de genocidio quede consumado, sin embargo, es necesaria la existencia de un plan dirigido al exterminio, físico o biológico, de los grupos protegidos, debido a que el genocidio es un delito intencional.

Con relación al concepto de grupo, digamos que los actos de genocidio pueden ser cometidos con la intención de destruir parcialmente al grupo como tal. La intención puede buscar la destrucción de un subgrupo. Alicia Gil Gil cita el Código Penal Federal de los Estados Unidos, el cual versa sobre la "destrucción total o en parte sustancial" de un grupo protegido como tal. Algunos consideran que el grupo protegido (bien jurídico protegido: la existencia de ciertos grupos como tales) se define por su "estabilidad". ${ }^{35}$ Otros, más que hablar del criterio de la estabilidad, se refieren a que Lemkin fue influenciado por la noción de "minorías nacionales" surgido después de la PGM. ${ }^{36}$ Este último punto de vista ("mino-

34 Ibidem, pp. 96 y 97. "Según la opinión dominante, el delito se perfecciona cuando cualquiera de las conductas individuales se consuma respecto de uno de los miembros del grupo. Es decir, basta una sola muerte - o cualquier otro de los resultados descritoscometida con la intención de destruir al grupo para que el delito quede consumado". Esta autora matiza: "basta la muerte cometida con la intención de participar con ella en una serie de acciones dirigidas a destruir el grupo, es decir, en un plan dirigido al exterminio del grupo".

35 Ibidem, p. 99. "El concepto de genocidio no se identifica con la idea de una matanza colectiva, sino que es más específico, consiste en el exterminio de un grupo humano estable como especie —o subespecie — zoológica y/o cultural".

36 Schabas, William, Genocide in International Law, Cambridge, Cambridge University Press, 2000, p. 105. "Lemkin's writings indicate he conceived of the repression of genocide within the context of the protection of what were then called 'national minorities'. Use de terms such as 'ethnic', 'racial' or 'religious' merely fleshed out the idea, without at all changing its essential content. But, among those who participated in deve- 
rías nacionales") implica que el hecho de haber excluido a los "grupos políticos" de los grupos protegidos por la Convención de Genocidio fue para facilitar la ratificación de la misma, más que una decisión basada en la distinción entre grupos estables y efímeros. ${ }^{37}$ Quien argumenta esto (Schabas), no sugiere que los grupos políticos deban ser incluidos dentro del tipo de genocidio. ${ }^{38}$ Alicia Gil Gil señala que la matanza masiva de personas pertenecientes a una misma nacionalidad tipifica crimen de lesa humanidad, pero no genocidio. El asesinato de disidentes u opositores a un régimen no entraría dentro del tipo penal de genocidio, debido a la ausencia del elemento subjetivo: la intención de destruir total o parcialmente a un grupo nacional, étnico, racial o religioso. Asimismo, indica que el grupo nacional no se define por sus caracteres ideológicos y que los grupos sociales, ideológicos, etcétera, fueron "excluidos del ámbito de protección del Convenio" (de Genocidio). Para esta autora, no es necesario "actualizar" el delito de genocidio en el sentido de incluir a los grupos políticos como grupos protegidos por este tipo penal, en virtud de que los mismos estarían protegidos por el tipo penal de crímenes contra la humanidad. ${ }^{39}$ Por su parte, Schabas señala que:

Durante décadas la Convención [de Genocidio] fue el único instrumento legal internacional que disfrutaba de una amplia ratificación y que imponía obligaciones significativas a los Estados en casos de atrocidades cometidas dentro de sus fronteras y por regla general por sus oficiales. La tentación de incluir una diversidad de conductas criminales del Estado dentro del ámbito de aplicación de la Convención era grande debido a la ausencia de otros instrumentos legales comparables. Este problema ha disminuido con el progresivo desarrollo en los recientes años del derecho penal internacional en el campo de las violaciones a los derechos humanos. ${ }^{40}$

loping the law of genocide in its early years, some saw the crime differently, and hoed to incorporate other groups within its scope".

37 Ibidem, p. 133.

38 Idem.

39 Ibidem, p. 158. "En mi opinión, los crímenes cometidos durante las dictaduras argentina o chilena no son encuadrables en el tipo de genocidio. Constituyen, en cambio, claramente, crímenes contra la humanidad, delito sobre el que nuestros tribunales [españoles] por desgracia no tienen competencia por el principio de jurisdicción universal, 1999".

40 Schabas, William, op. cit., nota 36, pp. 103 y 104. 


\section{Los grupos protegidos en la Convención de Genocidio}

Son cuatro los grupos protegidos por la Convención de Genocidio: nacional, racial, étnico y religioso. A juicio de William Schabas, dichos grupos deben verse como una totalidad, para efectos de determinar si estamos frente a un delito de genocidio o no. Como hemos dicho, Lemkin fue influenciado por la noción de "minorías nacionales", la cual fue "creada" entre la PGM y la SGM (Schabas). No es tan fácil aplicar la enumeración de los cuatro grupos protegidos. Esto puede ilustrarse - señala Schabas - mediante el caso del genocidio en Ruanda, ${ }^{41}$ ya que las diferencias "genómicas" entre tutsis y hutus no son siempre visibles en todos: hablan el mismo idioma, practican la misma religión y esencialmente comparten la misma cultura, tanto, que los colonizadores belgas establecieron cartas de identidad para diferenciarlos. Lo que delataba a los tutsis era su carta de identidad. En el caso de Kayishema and Ruzindana del Tribunal Penal Internacional para Ruanda (TPIR), se siguió un criterio subjetivo para determinar los grupos protegidos en el tipo penal de genocidio, estableciendo que la identidad del grupo podría ser establecida por otros, incluyendo los perpetradores. ${ }^{42}$ La debilidad que ve Schabas en este criterio subjetivo para la identificación del genocidio es que la ley penal no puede permitir definir el crimen solamente con el ofensor. Esto implica la necesidad de determinar algún criterio "objetivo" de existencia de los cuatro grupos definidos. Para ilustrar este punto, Schabas sugiere que el crimen de "trata de blancas" (white slavery), así como la erradicación de la prostitución forzada en escala internacional son relevantes actualmente a pesar de que el término es arcaico, algo similar ocurriría con el tipo penal de genocidio, creado convencionalmente en 1948. La consecuencia que Schabas obtiene de esta ilustración es que los cua-

41 Schabas, William, op. cit., nota 36, pp. 109 y ss.

42 Ibidem, p. 110; The Prosecutor versus Clément Kayishema and Obed Ruzindana, Case núm. ICTR-95-1-T http://69.94.11.53/ENGLISH/cases/KayRuz/judgement/4.htm, consultado en junio de 2008: "98. The intent must exist to "destroy a national, ethnical, racial or religious group, as such". Thus, the acts must be directed towards a specific group on these discriminatory grounds. An ethnic group is one whose members share a common language and culture; or, a group which distinguishes itself, as such (self identification); or, a group identified as such by others, including perpetrators of the crimes (identification by others). A racial group is based on hereditary physical traits often identified with geography. A religious group includes denomination or mode of worship or a group sharing common beliefs". 
tro grupos enlistados en la Convención de Genocidio deben verse como una totalidad y no autónomamente, como lo hace la legislación de los Estados Unidos (por ejemplo) y alguna jurisprudencia del TPIR. Cada uno de los cuatro grupos protegidos ayuda a definir los otros. No conviene definirlos autónomamente debido a que limitaría el ámbito de aplicación de la Convención de Genocidio.

El "grupo nacional" se ha definido con criterios contemporáneos, pero este intento - a juicio de Schabas - trae el curioso resultado de restringir el alcance de la Convención de Genocidio. "Nacionalidad" se ha caracterizado como una relación legal de una comunidad de personas con ciudadanía común; como un conjunto de relaciones históricas y culturales, etcétera. Incluso se ha llegado a hablar de "autogenocidio" como la matanza de miembros del grupo nacional del propio perpetrador (nacionales contra nacionales). Se cita el caso de Camboya como ejemplo, en el cual - se argumenta- un grupo intenta destruir a un grupo nacional de su misma nacionalidad. Al caso de Camboya, la legislación de los Estados Unidos le llama el "Auschwitz asiático".43

43 Para un punto de vista no estadounidense de lo ocurrido en Camboya, puede consultarse: Herman, Edward S., "Pol Pot And Kissinger, On War Criminality and Impunity", Z Magazine, http://musictravel.free.fr/political/political3.htm, consulta en junio de 2008, "The Times, along with everybody else in the mainstream media, also fails to mention that before Pol Pot came to power in 1975, the United States had devastated Cambodia for the first half of what a Finnish government's study referred to as a 'decade' of genocide (not just the four years of Pol Pot's rule, 1975-78). The 'secret bombing' of Cambodia by the Nixon-Kissinger gang may have killed as many Cambodians as were executed by the Khmer Rouge and surely contributed to the ferocity of Khmer Rouge behavior toward the urban elite and citizenry whose leaders had allied themselves with the foreign terrorists". Chomsky, Noam, op. cit., nota 32, p. 60. Este autor compara los hechos de 1977 y 1978 ocurridos en Camboya y Timor Oriental: Estados Unidos invocó los crímenes del Khmer Rouge para justificar otros peores, como los de Timor Oriental, donde "la violenta limpieza étnica y las atrocidades que aumentaron durante 1977 y 1978, alcanzando niveles que muchos consideraron de genocidas, con el número aproximado de 200 mil muertos, más de la cuarta parte de la población". Chomsky comenta que "la misión en ese momento [de los hechos en Camboya y Timor Oriental-Indonesia] era contribuir al enorme grito de rabia por los crímenes del Khmer Rouge, tarea que tuvo varios méritos: el agente inmediato era un enemigo oficial [el Khmer Rouge]; no había la menor sugerencia sobre cómo mitigar los crímenes - en marcado contraste con Timor y otras atrocidades mayores ocurridas al mismo tiempo-; Estados Unidos utilizaría estos crímenes masivos como justificación retrospectiva para cometer crímenes aun mayores en la guerra en Indonesia; y, quizá, lo más importante, podría invocar los crímenes para justificar otros futuros sobre la base de que detendrían a la 'izquierda del Pol Pot' $—$ sa- 
En 1999, el juez Baltasar Garzón sugirió que los hechos ocurridos en Argentina durante las décadas de los setenta y los ochenta del siglo pasado tipifican genocidio. Tesis adoptada de alguna manera por la justicia argentina en el caso Etchecolatz, al declararlo culpable de "delitos de lesa humanidad cometidos en el marco del genocidio que tuvo lugar en la República Argentina entre los años 1976 y 1983". ${ }^{44}$ A juicio de Schabas, confundir el asesinato en masa de un grupo nacional de la misma nacionalidad que el ofensor, no es consistente con la Convención de Genocidio, cuya intención fue proteger las minorías nacionales contra crímenes basados en el odio étnico. ${ }^{45}$ Este autor argumenta que dichos actos tipifican crímenes contra la humanidad, pero no genocidio. Grupo nacional significaría entonces "minoría nacional" o "minoría", y se define con relación a grupo racial, étnico o religioso conjuntamente, y no autónomamente. Igualmente que el grupo nacional, el "grupo racial" se ha definido con criterios contemporáneos, obteniéndose nuevamente el curioso resultado de limitar el alcance de la Convención de Genocidio, la cual - a juicio de Schabas - protege a cuatro grupos específicos cuyo significado fue definido después de la PGM con la noción de "minoría nacional". Por su parte, el TPIR define al grupo racial mediante factores físicos hereditarios con frecuencia identificados con una región geográfica. ${ }^{46}$ Cabe señalar que la ciencia ha puesto en entredicho el valor del término "racial" - señala Schabas - Incluso se ha afirmado que la noción de "raza" ha servido para justificar el colonialismo y la esclavitud (!!). Es por esto, por lo que la definición de "grupo racial" en la Convención de Genocidio se define a la par junto con los otros tres términos (étnico, nacional y religioso).

cerdotes y campesinos en El Salvador, por ejemplo... La atención a los enormes crímenes perpetrados con la decidida participación de Estados Unidos es una distracción poco adecuada".

44 "Veredicto contra Etchecolatz por crímenes contra la humanidad", Equipo Nizkor, http://www.derechos.org/nizkor/arg/ley/veredicto.html, consultado en junio de 2008.

45 Schabas, William, op. cit., nota 36, p. 119.

46 The Prosecutor versus Jean-Paul Akayesu, Case núm. ICTR-96-4-T, Judgement, http://69.94.11.53/ENGLISH/cases/Akayesu/judgement/akay001.htm\#art2, consultado en junio de 2008: " 514 . The conventional definition of racial group is based on the hereditary physical traits often identified with a geographical region, irrespective of linguistic, cultural, national or religious factors". Schabas, William, op. cit., nota 36, p. 120. 
El término "grupo racial" tenía un significado más amplio en el periodo de entreguerras del siglo XX — nos referimos a la PGM y la SGM-.

La noción de "grupo étnico" fue introducida por la sexta Comisión a propuesta de Suiza, para que el uso del término "grupo nacional" no se confunda con el de "grupo político". Los soviéticos consideraron que el grupo étnico es un subgrupo nacional. Otros Estados no encontraban diferencia entre grupos raciales y étnicos. Pero el mejor significado —nos dice Schabas - es tomarlo en conjunto con los otros tres grupos protegidos por la Convención de Genocidio (nacional, racial y religioso); esta interpretación — nos dice este autor- permite no restringir el alcance de la Convención de Genocidio. Los "grupos religiosos" formaron parte de los grupos protegidos en la Resolución 96 (I) de la Asamblea General de la ONU. El Reino Unido los objetó porque existe la libertad de permanecer o no en dichos grupos. Los soviéticos sugirieron que se incluyeran entre paréntesis al lado de los "grupos nacionales". Pero el argumento histórico de peso para incluir a los grupos religiosos dentro de los grupos protegidos en la Convención de Genocidio es que su protección surge en el ámbito de los tratados sobre minorías, posteriores a la PGM. A su vez, Egipto citó el caso de la masacre de San Bartolomét7 como ejemplo de

47 “Saint Bartholomew's Day, Massacre of”, Enciclopedia británica, la matanza o masacre de San Bartolomé (Massacre de la Saint-Barthélemy) es el asesinato en masa de hugonotes (calvinistas franceses) durante las guerras de religión de Francia del siglo XVI. Los hechos comenzaron el 24 de agosto de 1572 en París, extendiéndose durante los meses siguientes por toda Francia. Dumas, Alejandro, La reina Margarita, Porrúa, México, 1986, pp. 48, 58, 79, 85, 111 y 160./ — “Con que decididamente - dijo Coconas... ¿sois o no sois de la religión... [protestante, hugonote, calvinista francés]?/ — Suponed que lo sea — respondió La Mole con una sonrisa. ¿Tenéis alguna queja contra los protestantes?/ — iOh! ninguna, a Dios gracias. Los miro con la mayor indiferencia. Odio de todo corazón a la secta, pero no tengo mala voluntad a los hugonotes. Y sobre todo que ahora es moda serlo.../ —-Razón tenéis — gritó Coconnas—, ¡Mueran los hugonotes! Necesito vengarme, y cuanto antes mejor.../ — Esta noche caballero — dijo Carlos IX-, me quitan de en medio a todos los hugonotes.../ - Mi Majestad mata y pasa a cuchillo en este momento a cuantos no son católicos, porque así le agrada. ¿Sois católico vos? - exclamó Carlos cuya cólera crecía a cada momento como una terrible marea"./ -...Yo me alié a los hugonotes porque pensé que gozaban del favor real, pero hete aquí que los matan y dentro de ocho días no habrá cincuenta hugonotes en el reino... El degüello continuaba, aunque se iba atenuando la furia; tantos hugonotes habían matado, que su número era ya muy pequeño; la mayor parte habían muerto; muchos huyeron, otros estaban ocultos. De vez en cuando se alzaba una gritería en un barrio; era que ha- 
genocidio contra grupos religiosos, algo que ocurre también en sucesos en la India, Pakistán y Palestina. El TPIR (caso Kayishema) y la legislación de los Estados Unidos definen el grupo religioso como una colectividad con creencias comunes, pero esta definición restringe el alcance de la Convención de Genocidio - a juicio de Schabas-. Por su parte, el juez Baltasar Garzón en 1999 sugirió que podía cometerse genocidio contra "los no-Cristianos", o "todos los ateístas", etcétera. También se ha dicho que el Khmer Rouge practicó una política de erradicación de los rituales budistas, así como la ejecución de líderes budistas recalcitrantes, etcétera, pero estos hechos - dice Schabas- están más cerca del "genocidio cultural" (excluido de la Convención) que del genocidio físico contra un grupo religioso, en virtud de que la intención del Khmer Rouge, no era la de destruir a los miembros de la religión budista como tales, sino la de destruir los rituales de la religión budista. Schabas insiste en la necesidad de definir los grupos protegidos por la Convención de Genocidio en conjunto y no autónomamente (TPIR, Estados Unidos) y ser vistos a la luz de la noción de "minorías nacionales" surgida después de la PGM, para no restringir la aplicación de dicha Convención.

\section{GÉNESIS DEL TIPO PENAL DE GENOCIDIO}

El genocidio se inserta en lo que se ha dado en llamar el Derecho Penal Internacional, el cual nace con la intención de castigar los crímenes de guerra ocurridos durante la SGM y para prevenir que se cometan nuevamente delitos tan graves como los cometidos en dicha conflagración mundial. ${ }^{48}$ Después de la Primera Guerra Mundial, en 1919 se firma el Tratado de Versalles, el cual contempló la sanción de: 1. ofensas a la moralidad internacional; 2 . ofensas a la sacrosanta inviolabilidad de los tratados; y 3. acciones contrarias a los derechos y costumbres de la guerra. ${ }^{49}$

bían descuidado a uno de estos últimos. Su ejecución era entonces privada o pública, era cuando se acorralaba al infeliz en algún sitio sin salida, ora cuando podía escapar... En dos palabras os explicaré la política de todos. Mi hermano Carlos mata a los hugonotes para reinar más libremente. Mi hermano Anjou los deja matar porque debe suceder a mi hermano Carlos, que está casi siempre enfermo...".

48 Hernández Pacheco, Susana, "El derecho penal internacional y el Proyecto de la Comisión de Derecho Internacional de la ONU relativo al Estatuto de un Tribunal Penal Internacional", Lex, Difusión y Análisis, 3a. época, año I, octubre 1995, núm. 4.

49 Ibidem, p. 69. 
En el marco del Tratado de Versalles se crea la Comisión sobre la Responsabilidad de los Autores de la Guerra y la Aplicación de Sanciones. Esta Comisión habló de "Violaciones a las Leyes y Costumbres de Guerra y a las Leyes de Humanidad". ${ }^{50}$ Algunos de estos crímenes incluían la persecución de minorías étnicas o grupos. La Comisión mencionada hizo referencia a actos de autoridades alemanas, búlgaras y austriacas, quienes prohibieron el uso del idioma serbio o que destruyeron archivos, iglesias y llegaron a clausurar escuelas, etcétera. Fue tal la violencia cometida, que se sugirió la exclusión de la amnistía a los responsables por crímenes contra las leyes y costumbres de la guerra y de las leyes de humanidad y en la Conferencia de Paz, el ministro de Relaciones Exteriores de Grecia propuso una nueva categoría de crímenes de guerra: crímenes contra las leyes de humanidad. El entonces presidente de los Estados Unidos, Woodrow Wilson, consideró la propuesta como una ley creada ex post facto o condenada a la ineficacia. ${ }^{51}$ El artículo 227 del Tratado de Versalles estipuló que el Kaiser Guillermo II debía ser enjuiciado. Esto nunca ocurrió porque Holanda (país donde se exiló Guillermo II) nunca otorgó la extradición del Kaiser. Pero los artículos 228 a 230 de dicho tratado permitieron la creación de tribunales internacionales de crímenes de guerra (los primeros en la historia)..$^{52}$

El 10 de agosto de 1920 se firma el Tratado de Sèvres (Francia), tratado de paz entre Turquía (Imperio otomano) y los países aliados (excepto

50 Schabas, William, op. cit., nota 36, p. 18.

51 Ibidem, p. 19.

52 Schabas, William, op. cit., nota 36, p. 19; Gómez-Robledo Verduzco, Alonso, "Notas sobre el principio de complementariedad y el crimen de agresión en el marco de la Corte Penal Internacional”, en García Ramírez, Sergio y Vargas Casillas, Leticia A. (coord.), Proyectos legislativos y otros temas penales, México, UNAM, Instituto de Investigaciones Jurídicas, 2003, p. 308. "Anteriormente, como se sabe, el Tratado de Versalles de 1919, había estipulado el principio de la responsabilidad de Alemania y sus aliados, por haber llevado a cabo una 'guerra no justa', y paralelamente se previó la responsabilidad del Kaiser Guillermo II, emperador de Alemania, ante un tribunal internacional por violación de ciertos tratados, como los de Neutralidad de Bélgica, Luxemburgo y los Países Bajos. Al negar la extradición del Kaiser, el artículo 227 quedó en letra muerta”. García Ramírez, Sergio, Los derechos humanos y la jurisdicción interamericana, México, UNAM, Instituto de Investigaciones Jurídicas, 2002, "La materia penal, sede de la responsabilidad necesariamente individual de los autores de delitos, como ya señalé, se halla atendida por diversos órganos jurisdiccionales de carácter internacional, a partir del fallido intento por instituir un tribunal de esta naturaleza previsto en el Tratado de Versalles para el enjuiciamiento del ex kaiser Guillermo II". 
Rusia y Estados Unidos). Los aliados consideraron la sanción a los malos tratos ocasionados a los prisioneros de guerra (principalmente ingleses), así como las deportaciones y masacres, es decir, las persecuciones contra las minorías armenias. ${ }^{53} \mathrm{El}$ Tratado de Sèvres contempló el delito de lesa humanidad, sin embargo nunca fue ratificado, y fue remplazado por el Tratado de Lausana de 1923 el cual otorgó la amnistía por todas las ofensas cometidas entre el 1o. de agosto de 1914 y el 2o. de noviembre de $1922 .{ }^{54}$ Durante el periodo de las dos guerras mundiales, surgen ideas respecto de la creación de una corte penal internacional. La Asociación de Derecho Internacional y la Asociación Internacional de Derecho Penal estudiaron la cuestión de la jurisdicción penal internacional. ${ }^{55}$

En 1937 la Liga de las Naciones adoptó un tratado que contemplaba la creación de una Corte Penal Internacional (CPI). En 1938, la Octava Conferencia Internacional de los Estados Americanos consideró la persecución por motivos raciales o religiosos. Cabe señalar que Hitler anexó a Austria en 1937 y los Sudetes (Checoslovaquia) en septiembre de 1938. ${ }^{56}$ El 1o. de septiembre de 1939 Hitler habría de invadir Polonia utilizando un ardid. ${ }^{57}$ Después de la PGM, la comunidad internacional creó un siste-

53 Schabas, William, op. cit., nota 36, p. 20.

54 Kaplan, Marcos, El Estado y la globalización, México, UNAM, Instituto de Investigaciones Jurídicas, 2002, p. 197. "Ya en 1920, Turquía se rebela contra el Tratado de Sèvres, y fuerza su revisión por el Tratado de Lausanne".

55 Schabas, William, op. cit., nota 36, pp. 22 y ss.

56 “Hitler, Adolf", Encyclopcedia Britannica 2006, Suite DVD-2006.

57 Delarue, Jacques, La Gestapo, Barcelona, Bruguera, 1972, p. 207. "Como la política de agresión les había reportado una victoria tras otra, Hitler y sus secuaces no pensaron ni por un instante en cambiar de método. Desde finales de 1938 ya estaba tomada la decisión de anexionarse Polonia. La ciudad libre de Dantzig, aislada en territorio polaco por el Tratado de Versalles, podía invocarse como pretexto. Los móviles hitlerianos no necesitaban un aparato teatral semejante al empleado en Austria y Checoslovaquia. Polonia debía transformarse en territorio de expansión, de repoblación. Constituía la primera etapa de la conquista de aquel lebesraum, de aquel "espacio vital" que Hitler reivindicaba desde los primeros años del nazismo... Para inventar un incidente que permitiera acusar a los polacos de provocación, Hitler pensó, naturalmente, en su ejecutor favorito para toda clase de bajezas, Himmler... El plan de maquinación concebida por Himmler, cuya realización fue confiada a Heydrich, recibió el nombre en clave de "operación Himmler". Para su ejecución, Heydrich escogió a un hombre de su confianza, Alfred Helmut Naujocks, uno de sus íntimos amigos, al que conoció en Kiel cuando, después de ser rechazado por la Marina, ingresó en las S. S. Mecánico de oficio y boxeador por afición... El 10 de agosto de 1939... Heydrich le encargó simular un ataque contra la emisora de radio alemana situada en Gleiwitz (Alta Silesia), cerca de la frontera polaca, 
ma de protección para las minorías nacionales, garantizando su derecho a la vida. El sistema se enfocaba en grupos vulnerables identificados por su nacionalidad, etnicidad o religión. ${ }^{58}$ Éstos serían los mismos grupos que serían protegidos por la Convención de Genocidio de 1948. Este sistema de protección de minorías nacionales contribuiría al trabajo de Raphael Lemkin, creador del término "genocidio".

Lemkin nació en Polonia el 24 de junio de 1900. Allí ejerció como abogado, fiscal y profesor universitario. Como judío dejó Polonia para trasladarse a los Estados Unidos, donde encontró trabajo en la Duke University y posteriormente en la Yale University. ${ }^{59}$ Fue consejero del secretario general de las Naciones Unidas en la creación del proyecto de la Convención de Genocidio. Crea el término "genocidio" con la palabra genos, que en griego significa raza, nación o tribu, y de la palabra cide, del latín que significa matar. Su interés en el fenómeno del "genocidio" data desde su época de estudiante en la Universidad de Lvov en Polonia, época en la que se intentaba sancionar a los responsables de las masacres turcas contra los armenios. ${ }^{60}$

En octubre de 1933, Lemkin propone el reconocimiento de los delitos de vandalismo y barbarie, durante la quinta Conferencia Internacional

en la forma que le explicó. El simulacro tendría la apariencia de una agresión cometida contra la estación por un comando polaco".

58 Schabas, William, op. cit., nota 36, p. 23. Este autor sugiere que los legisladores de entonces parecían presentir el holocausto.

59 Ibidem, pp. 24 y ss.; "Raphael Lemkin", Wikipedia, The Free Encyclopedia, en http://en.wikipedia.org/wiki/Raphael_Lemkin, consultado en octubre de 2006.

60 "Armenia", Enciclopedia británica, CD-ROM, 2003, "The greatest single disaster in the history of the Armenians came with the outbreak of World War I. In 1915 the young Turk government resolved to deport the whole Armenian population of about 1,750,000 to Syria and Mesopotamia. It regarded the Turkish Armenians - despite pledges of loyalty by many - as a dangerous foreign element bent on conspiring with the pro-Christian tsarist enemy to upset the Ottoman campaign in the east. In what would later be known as the 'first genocide' of the 20th century, hundreds of thousands of Armenians were driven from their homes, massacred, or marched until they died. The death toll of Armenians in Turkey has been estimated at between 600,000 and 1,500,000 in the years from 1915 to 1923 . Tens of thousands emigrated to Russia, Lebanon, Syria, France, and the United States, and the western part of the historical homeland of the Armenian people was emptied of Armenians". Los turcos niegan haber cometido genocidio contra los armenios. Otros datos pueden consultarse en Chomsky, Noam, op. cit., nota 32. 
para la Unificación del Derecho Penal, celebrada en Madrid. ${ }^{61}$ Propuso que se incluyeran dichos delitos en las legislaciones de los países asistentes. ${ }^{62}$ En la construcción del delito de barbarie destacó los siguientes elementos: 1. que el empleo de la violencia prueba los móviles antisociales y crueles de los autores; 2 . una la acción sistemática y organizada; 3. que la acción no se dirige contra personas determinadas, sino contra la población o un grupo de ciudadanos, es decir, dirigida contra cierta colectividad; 4. dicha colectividad está indefensa; y, 5. la intención con que se realiza puede consistir en la intimidación de la población. ${ }^{63}$ Lemkin definió el vandalismo como la destrucción dolosa de obras de arte y de cultura de importancia reconocida. No se hace referencia a que dichas obras pertenezcan a cierto grupo. En noviembre de 1934 surge en Lemkin la imagen de lo que sería posteriormente el delito de genocidio. En este esquema (1934) la lucha de exterminio se encarnaría en la barbarie y el vandalismo. ${ }^{64}$

El término de "genocidio" aparece en la obra de Lemkin en 1944 en su celebrada obra Axis Rule in Occupied Europe. Dice que el delito de genocidio es una "vieja práctica en su desarrollo moderno". ${ }^{65}$ Describe el

61 Gil Gil, Alicia, Derecho penal internacional, Madrid, Tecnos, 1999, p. 151; Schabas, William, op. cit., nota 36, p. 27.

62 Gil Gil, Alicia, op. cit., nota 9, p. 151. "En aquella primera elaboración, tal y como se recoge en las actas de la conferencia, no es posible todavía ver en ambos delitos un claro precedente del genocidio".

63 Gil Gil, Alicia, El genocidio y otros crimenes internacionales, Valencia, Centro Francisco Tomás y Valiente-UNED Alzira-Valencia, 1999, pp. 125 y 126.

64 Ibidem, pp. 126 y 127. "Artículo 1o. Quien por odio a una raza, o comunidad confesional o social, o con el propósito de su destrucción emprenda un acto punible contra la vida, la salud, la libertad, la dignidad o la existencia económica de una persona perteneciente a dicha comunidad será castigado por delito de barbarie con la pena de prisión con una duración de... en tanto su acción no conlleve una pena mayor según un precepto más severo del Código penal. La misma pena recibirá el autor en caso de que su acción se haya dirigido contra una persona que haya mostrado su solidaridad con dicha comunidad o que la defienda sin pertenecer al mismo. Artículo 2o. Quien por odio a una comunidad descrita en el artículo anterior o con el propósito de su destrucción destruye obras culturales o artísticas de las mismas será castigado por delito de vandalismo con le pena de prisión con una duración de... en tanto en cuanto su acción no conlleve una pena mayor según otra disposición del Código Penal. Artículo 3o. Los hechos delictivos descritos en los artículos anteriores serán perseguidos y castigados por el Estado en el que el autor haya sido apresado, con independencia del lugar de comisión del hecho y de la nacionalidad del autor".

65 Schabas, William, op. cit., nota 36, p. 27. 
genocidio como aquellas acciones encaminadas a la destrucción de los fundamentos esenciales de la vida del grupo con el propósito de aniquilar al grupo como tal. El objetivo es la destrucción de las instituciones políticas y sociales, la cultura, el lenguaje y los sentimientos nacionales. Descarta el término "asesinato de masas" o "exterminio" porque no aluden al móvil específico de destruir un grupo. ${ }^{66} \mathrm{El}$ genocidio implica un plan coordinado para destruir las manifestaciones esenciales de la vida de grupos nacionales con el fin de destruirlos. Las acciones del genocidio se dirigen contra la entidad grupal, no contra los individuos, es decir, las acciones cometidas contra los individuos se entienden, pero como individuos pertenecientes al grupo nacional. Lemkin concibe dos etapas del genocidio: 1. la destrucción de la estructura nacional del grupo oprimido; y 2. la imposición de la estructura del opresor. Menciona el concepto de "desnacionalización" de 1919 para ilustrar este fenómeno. Después vendría la "germanización" durante la Alemania de Hitler. El genocidio implica entender que la guerra no se comete contra ejércitos y soberanos, sino contra los ciudadanos. ${ }^{67}$

Lemkin recomendó que el delito de genocidio fuese prohibido tanto en tiempo de guerra como de paz. Propuso la introducción en el derecho doméstico de normas de protección de grupos minoritarios nacionales, religiosos o raciales. La obediencia debida no sería excluyente de responsabilidad y su persecución debía ser conforme a un principio de represión universal — como lo es la "esclavitud blanca” y la piratería-. Es un delito de tal gravedad que conmociona la conciencia de la humanidad y debe existir la obligación de la cooperación internacional para su represión. Es cometido por el Estado o con su apoyo.

Cabe señalar que en el Tribunal de Nüremberg, el fiscal británico, sir Hartley Schawkross, utilizó el término genocidio, pero no fue utilizado

66 Gil Gil, Alicia, op. cit., nota 61, p. 152.

67 Ibidem, p. 153. "La guerra para los alemanes era una guerra contra los Estados, sus ejércitos y su población. De esta forma, la guerra ofreció a los ocupantes la ocasión propicia para llevar a cabo su programa de genocidio. En opinión de Lemkin, el genocidio fue para los alemanes una técnica de ocupación destinada a darles la victoria en la paz aunque la guerra se perdiera. Con esta intención el ocupante habría elaborado un sistema destinado a destruir las naciones según un plan previamente preparado. En la concepción del Mekin, Hitler había previsto el genocidio como medio de cambiar las proporciones en Europa a favor de Alemania, pues la germanización podía hacerse, en la mentalidad de este último, sólo sobre el suelo, pero nunca sobre los hombres". 
en la sentencia final. Todavía no era clara la diferencia entre delito de lesa humanidad y genocidio. ${ }^{68} \mathrm{E}$ fiscal francés también utilizó el término genocidio para referirse al "exterminio científico y sistemático de millones de vidas humanas y más especialmente de ciertos grupos nacionales y religiosos cuya existencia obstaculizaba la hegemonía de la raza germana". ${ }^{69}$

Durante la SGM se plantea nuevamente el tema de la responsabilidad penal por crímenes de guerra. El 1o. de noviembre de 1943 surge la Declaración de Moscú (Conferencia de Moscú), en la que se anuncia la voluntad de las potencias aliadas para castigar a los criminales de guerra. ${ }^{70}$ Allí se fijó el modelo de enjuiciamiento posterior a la terminación de la guerra. Dicha declaración fue firmada por Stalin, Churchill y Roosevelt..11

68 Ibidem, pp. 154 y 155. "Las similitudes del concepto de genocidio con ciertas concepciones del crimen contra la humanidad... y la falta de un tipo específico en el Estatuto del Tribunal de Nüremberg, han provocado que con frecuencia se califique al genocidio como una especie del crimen contra la humanidad, y a pesar de que el nombre de 'genocidio' no aparece ni en el Estatuto ni en las sentencias del Tribunal de Nüremberg, sí fue utilizado en alguna ocasión en los alegatos de la acusación o aparece como especie del crimen contra la humanidad en alguna sentencia de los tribunales militares americanos cuando todavía no se había elaborado la convención sobre el genocidio, pero la Asamblea General había adoptado recientemente la Resolución 96 (I) del 11 de diciembre de 1946. Sin embargo, el estudio histórico y dogmático del delito de genocidio... nos llevará a ver, que si bien es cierto que el mismo tuvo su origen en aquéllos, la evolución de ambos conceptos conduce a su diferenciación e independencia actual".

69 Gil Gil, Alicia, op. cit., nota 63, p. 131.

70 Cabe señalar que el 2 de febrero de 1943, el mariscal del campo alemán, Friedrich Wilhelm Ernst Paulus (Breitenau, 23 de septiembre de 1890-Dresde, el 1o. de febrero de 1957), se rinde al Ejército Rojo en Stalingrado (hoy Volvogrado y antes Tsaritsyn). Véase "Paulus, Friedrich", Enciclopedia Británica, CD-ROM, 2003.

71 Gil Gil, Alicia, op. cit., nota 63, p. 36. "Durante la Segunda Guerra Mundial los aliados denunciaron en numerosas ocasiones las atrocidades cometidas por las potencias del Eje y su intención de castigarlas. Especial mención merecen la Declaración de Saint-James firmada en Londres el 13 de enero de 1942 y la Declaración de Moscú del 30 de octubre de 1943 firmada por Stalin, Roosvelt y Churchill, que fijó el modelo de enjuiciamiento que se seguiría tras la guerra. Entre las denuncias se incluían las de los actos cometidos contra los propios nacionales alemanes y contra ciudadanos de países neutrales". Hernández Pacheco, Susana, op. cit., nota 48, p. 69. "Durante la segunda guerra mundial otros instrumentos internacionales plantearon nuevamente la cuestión de la responsabilidad penal por crímenes de guerra. Finalmente, el 1o. de noviembre de 1943 se publicó en Moscú una declaración conjunta de las principales potencias que luchaban contra los países del Eje, que anunciaba su voluntad de castigar a los criminales de guerra"; "Resolución del juez federal Gabriel R. Cavallo declarando la inconstitucionalidad 
Entonces se crea la Comisión de las Naciones Unidas sobre Crímenes de Guerra, cuyo problema era determinar el derecho aplicable a los responsables por los crímenes cometidos durante la SGM. Debía fundamentarse la competencia y el derecho aplicable. Inicialmente, esta Comisión usó la lista de ofensas proyectadas en la Comisión de Responsabilidades de la Conferencia de Paz de París de 1919. ${ }^{72}$ Esta lista incluía el delito de "desnacionalización", así como el asesinato y maltrato de civiles. La Comisión crea un proyecto de Convención para el Establecimiento de un Tribunal de Crímenes de Guerra de las Naciones Unidas. La representación estadounidense en el Comité Legal de la Comisión utilizó el término crimen contra la humanidad, como ofensas cometidas contra cualquier persona por razón de su raza o religión. Uno de los problemas con que se encontró esta Comisión es que debía encontrar un texto que permitiese el castigo de conductas cometidas contra los propios nacionales. ${ }^{73} \mathrm{El} 8$ de agosto de 1945, en la Conferencia de Londres de 1945, se aprueba la Carta del Tribunal Militar Internacional. ${ }^{74}$ En diciembre de 1945, las potencias aliadas (Estados Unidos, Francia, Reino Unido y la URSS) promulgan la Ley núm. 10 del Consejo del Control Aliado, una especie de versión modificada de la Carta del Tribunal de Nüremberg, ${ }^{75}$ en la cual

y la nulidad insanable de los artículos 1o. de la Ley de Punto Final y 1o., 3o. y 4o. de la Ley de Obediencia Debida", Equipo Nizkor, http://www.derechos.org/nizkor/arg/ley/ juezcavallo03mar.html, consultado en junio de 2008; "el 1o. de noviembre de 1943, se produjo la "Declaración de Moscú", firmada por el presidente Roosevelt, el primer ministro Winston Churchill y el mariscal Stalin, en la que anunciaron que los culpables de los crímenes serían perseguidos hasta el 'confín de la tierra y puestos en manos de sus acusadores para que se haga justicia"”; Moscow Conference, October, 1943, Joint Four-Nation Declaration, http://www.ibiblio.org/pha/policy/1943/431000a.html, consultado en junio de 2008.

72 Schabas, William, op. cit., nota 36, p. 31.

73 Gil Gil, Alicia, op. cit., nota 63, p. 37.

74 Hernández Pacheco, Susana, op. cit., nota 48, p. 69; Gil Gil, Alicia, op. cit., nota 63, p. 37; Schabas, William, op. cit., nota 36, pp. 36 y 37.

75 Jovasevic, Dragan, "NATO Genocide in FR of Yugoslavia", Review of International Affaire, vol. LI, núm. 1091-93, abril-junio de 2000, p. 62. "The London Agreement of the tour powers - the USA, the USSR, the United Kingdom and France- of Augusto 8,1945 , had, in its thirty articles or so, for the first time, practically determined the jurisdiction of the International Military Tribunal, its composition, the persons subject to prosecution, the task of the prosecutor, the rights of the defendants, and the international crimes the perpetrators of which are liable to be tried before this Tribunal and on which judgment shall be passed". Hernández Pacheco, Susana, op. cit., nota 48, p. 69. "El 8 de 
se elimina el nexo a una situación de guerra de los crímenes cometidos. ${ }^{76}$ El Tribunal de Nüremberg es competente para conocer de los crímenes contra la paz, crímenes de guerra y crímenes contra la humanidad. ${ }^{77}$ En el Estatuto de Londres se establece: 1. la irrelevancia del carácter oficial, es decir, el carácter oficial del inculpado no exime ni atenúa responsabilidad; y, 2. la irrelevancia de la obediencia debida. La competencia territorial del Tribunal de Nüremberg consistió en: 1. juzgar los delitos cometidos por los alemanes en el territorio de un país ocupado; y, 2. juzgar los crímenes que no pudieran ser determinados en un lugar geográfico determinado. El juicio final de Nüremberg no usa el término "genocidio", pero Lemkin consideró que dicho juicio es un "amplio soporte al concepto de genocidio". ${ }^{78}$ Los Juicios de Nüremberg mantienen la conexión entre los crímenes contra la humanidad con respecto a una situación de guerra, aunque en la Ley núm. 10 del Consejo del Control Aliado del 20 de diciembre de 1945, se prescindió dicha conexión. ${ }^{79}$ Pero la Resolución 95 (I) del 11 de diciembre de 1946, de la Asamblea General de las Naciones Unidas, sobre los "Principios de Nüremberg", mantiene la exigencia de la conexión entre los crímenes contra la humanidad y una situación de guerra. ${ }^{80}$ Rápidamente, la doctrina exigió la desconexión de los crímenes contra la humanidad a una situación de guerra. Era necesario un concepto nuevo de crimen contra la humanidad. ${ }^{81}$

\section{La Corte Penal Internacional}

A partir de la SGM se ve la necesidad de crear una CPI que defina y sancione los delitos internacionales considerados de tal gravedad que lesionan la conciencia de la humanidad. La CPI es el producto, principalmente, de la Comisión de Derecho Internacional (CDI) de la Organización de las Naciones Unidas. El 21 de noviembre de 1947, mediante la Resolución 177 (III), la Asamblea General de la ONU solicita a la CDI: 1. formular los principios de derecho internacional de la Carta del Tribunal de Nüremberg y del juicio del mismo tribunal y 2. preparar un proyecto de Crímenes Contra la Paz y Seguridad de la Humanidad, en concordancia con los principios mencionados en el punto anterior. ${ }^{82} \mathrm{La}$ CDI formuló un proyecto de Código de Crímenes Contra la Paz y Seguridad de la Humanidad en $1951 .{ }^{83}$ Después de realizadas ciertas modificaciones, el proyecto fue puesto en consideración de la Asamblea General de la ONU nuevamente en 1954, la cual suspendió la consideración del pro- 
yecto, en el entendido de que el código y la definición de agresión sean preparados por un comité especial interrelacionado con un reporte aún inconcluso. ${ }^{76} \mathrm{El}$ problema de este proyecto de código es la definición de agresión, que teóricamente no representa realmente un problema. La Asamblea General, mediante la Resolución 3314 (XXIX) del 14 de diciembre de 1974, define el crimen de agresión como "el uso de la fuerza armada por un Estado contra la soberanía, integridad territorial o la independencia política de otro Estado, o en cualquier otra manera inconsistente con la Carta de las Naciones Unidas. En 1991, la CDI aprueba en primera lectura el proyecto de Código de Crímenes Contra la Paz y Seguridad de la Humanidad. Este proyecto de 1991 incluye la cuestión del establecimiento de una $\mathrm{CPI}^{77}$ y define los crímenes de: 1. agresión; 2. amenaza de agresión; 3. intervención; 4. dominación colonial y extranjera; 5. genocidio; 6. apartheid; 7. violación sistemática y masiva de los derechos humanos; 8. crímenes de guerra de gravedad excepcional; 9. terrorismo internacional; 10. tráfico ilícito de estupefacientes; y 11. daños deliberados y graves al medio ambiente. ${ }^{78} \mathrm{La}$ definición de estos crímenes fue retomada en 1995 por la CDI. En el Proyecto de Crímenes Contra la Paz y Seguridad de la Humanidad de la CDI (1996) se definen los crímenes de: 1. agresión; 2. genocidio; 3 . crímenes contra la humanidad; y 4. crímenes de guerra. ${ }^{79}$ Este proyecto incluye el tema del Estatuto de la CPI. En 1996, mediante su Resolución A/RES/51/207, la Asamblea General de la ONU decide que la conferencia diplomática de plenipotenciarios se efectúe en 1998 con la finalidad de finalizar y adoptar la convención para el establecimiento de una CPI y urge al mayor número de Estados que participen en el Comité Preparatorio con el objeto de pro-

76 ILC, A/CN.4/364, 1983, First report on the draft of offences against the peace and security of mankind, by Mr. D. Thiam, Special Rapporteur, p. 141, http://untreaty.un.org /ilc/documentation/english/a_cn4_364.pdf, consultado en junio de 2008.

77 A/CN.4/SER.A/1991/Add.1 (Part I), Yearbook of the International Law Commission, 1991, vol. II (Part One), http://untreaty.un.org/ilc/publications/yearbooks/Ybkvolu mes(e)/ILC_1991_v2_p1_e.pdf, consultado en junio de 2008.

78 Hernández Pacheco, Susana, op. cit., nota 48, p. 70.

79 A/CN.4/L.522, Draft Code of Crimes against the Peace and Security of Mankind. Titles and texts of articles adopted by the Drafting Committee on second reading at the forty-seventh and forty-eighth sessions - reproduced in document A/CN.4/SR.2437, para.7, http://untreaty.un.org/ilc/documentation/english/a_cn4_l522.pdf, consultado en junio de 2008. 
mover el apoyo universal para una CPI, etcétera. ${ }^{80}$ En 1997, la Asamblea General acepta el ofrecimiento del Gobierno de Italia para fungir como anfitrión de la Conferencia de Plenipotenciarios para el Establecimiento de una CPI, y abre dicha Conferencia a todos los miembros de la ONU o de las agencias especializadas o de la Agencia Internacional de Energía Atómica, a realizarse en Roma en 1998 para la finalización y adopción de una convención para el establecimiento de una CPI; invita a diversas organizaciones y otras entidades a participar incluyendo a los tribunales para la antigua Yugoslavia y Ruanda; etcétera. ${ }^{81} \mathrm{En}$ su resolución A/RES/53/105, la Asamblea General reconoce la importancia del hecho de haberse adoptado el Estatuto de Roma (Estatuto de la CPI). Un gran paso se había dado, después que el 8 de agosto de 1945 mediante el Acuerdo de Londres se adopta el Estatuto del Tribunal de Nüremberg, considerado el primer código de ley penal internacional. ${ }^{82}$ El Estatuto de la CPI entra en vigor el 10 . de julio de 2002, habiendo reunido las ratificaciones mínimas necesarias. ${ }^{83}$ La CPI limita su competencia a los delitos más graves, entre ellos, el de genocidio.

\section{EL CASO CAVALLO}

El 25 de agosto de 2000, el Juzgado Central de Instrucción número cinco de la Audiencia Nacional de Madrid, España, con base en el artículo 19 del Tratado de Extradición y Asistencia de Mutua en Materia Penal entre México y España, solicitó a la Secretaría de Relaciones Exteriores de México (SRE) la detención preventiva de Ricardo Miguel Cavallo (alias "Sérpico", en adelante Cavallo) con fines de extradición internacional por la supuesta responsabilidad de los delitos de genocidio, tortura

$80 \mathrm{~A} / \mathrm{RES} / 51 / 207$, Establishment of an international criminal court, Adopted at the 88th plenary meeting, 17 Dec. 1996, Adopted without vote, 88th meeting.

$81 \mathrm{~A} / \mathrm{RES} / 52 / 160$, Establishment of an international criminal court.

82 Sánchez Larios, Eligio, op. cit., nota 75, p. 70.

83 "El 1o. de julio de 2002, con 76 ratificaciones y 139 firmas, entró en vigor Estatuto de Roma de la Corte Penal Internacional del 17 de julio de 1998. El 11 de abril de 2002 se reunió el número mínimo de ratificaciones necesarias para su entrada en vigor". Véase Equipo Nizkor, http://www.derechos.org/nizkor/impu/tpi/, consultado en junio de 2008. 
y terrorismo. ${ }^{84}$ La petición de detención preventiva fue remitida a la Procuraduría General de la República mexicana (PGR). En esta misma fecha, el procurador general de la República solicitó al juez de Distrito en Materia Penal en el Distrito Federal, decretar la detención preventiva de Cavallo con fines de extradición internacional. El juez de Distrito concedió el decreto de la detención preventiva contra Cavallo el 26 de agosto de 2000.

Cavallo quedó a disposición del juez de Distrito en el Reclusorio Preventivo Varonil Oriente del Distrito Federal (Reclusorio). El 13 de septiembre de 2000, el juez Baltasar Garzón Real (juez Garzón), resuelve solicitar la extradición de Cavallo para ser procesado por los delitos de genocidio, terrorismo y tortura. El 15 de octubre de 2000, la Embajada del Reino de España en México (Embajada española) presentó a la SRE la petición de formal extradición internacional contra Cavallo para ser procesado por los delitos mencionados. La petición formal de extradición internacional fue remitida a la PGR. El 10 de octubre de 2000, el juez de Distrito tuvo por presentada en tiempo y forma la solicitud, sujetando a Cavallo al procedimiento de extradición internacional.

El 11 de enero de 2001, el juez de Distrito —en la etapa de opinión de la extradición internacional- consideró parcialmente procedente la extradición internacional de Cavallo, solicitada por la PGR - a petición de la Embajada española - por los delitos de genocidio y terrorismo, pero no por el de tortura, ya que este último delito lo consideró prescrito. Por otra parte, el 2 de febrero de 2001, la SRE expidió el acuerdo que concedió la extradición de Cavallo a España para ser juzgado por los delitos de genocidio, terrorismo y tortura. ${ }^{85}$ Cavallo recurrió al amparo contra el Acuerdo de la SRE y la validez constitucional del Tratado de Extradición y Asistencia Mutua en Materia Penal, entre los Estados Unidos Mexicanos y el Reino de España (Tratado de Extradición), celebrado el 21 de noviembre de 1978, el Protocolo del mismo instrumento suscrito el 23 de junio de 1995, por el que se modificaron ciertas disposiciones del tratado en cuestión y la Convención de Genocidio, instrumento multilate-

84 Suprema Corte de Justicia de la Nación, Amparo en Revisión 140/2002, www.sc jn.gob.mx/NR/rdonles/1E5C9300-BAD2-46C5-ADBD-199EDB9068E1/0/Amparoenrevi sión1402002dePleno.pdf, consultado en junio de 2008.

85 Becerra Ramírez, Manuel, "El caso Cavallo", Anuario Mexicano de Derecho Internacional, México, vol. IV, 2004, p. 586. 
ral del que son parte tanto México como España. ${ }^{86} \mathrm{El} \mathrm{juez} \mathrm{de} \mathrm{Distrito,} \mathrm{en}$ audiencia constitucional del amparo indirecto, resolvió: 1. otorgar el amparo contra la extradición internacional en lo concerniente al delito de tortura, en virtud de que — consideró- ha prescrito; 2 . no se otorga el amparo contra la extradición internacional por los delitos de genocidio y terrorismo; 3. niega la inconstitucionalidad de los instrumentos internacionales impugnados. Contra dicha resolución, Cavallo presentó el recurso de revisión por los agravios que le causaba. La SRE impugnó también el fallo del juez de Distrito aduciendo que el delito de tortura no ha prescrito, y que por lo tanto, debía negarse la protección de la justicia federal al quejoso. El Ministerio Público también impugnó la resolución del juez de Distrito y argumentó el mismo agravio que la SRE (imprescriptibilidad del delito de tortura). La Suprema Corte de Justicia de la Nación mexicana (SCJN), con base en el artículo 107, fracción III, inciso a, de la Constitución federal mexicana, ejerció la facultad de atracción estimándose competente para conocer del asunto.

La SCJN resolvió finalmente el 10 de junio de 2003, de la siguiente manera: 1. confirma el amparo contra el acuerdo de la SRE en lo que corresponde al delito de tortura por encontrarse prescrito, así como contra la ejecución atribuida a la PGR y el Reclusorio; 2 . no se concede amparo contra el acuerdo de la SRE; 3 . No se concede amparo contra el proceso de creación de los instrumentos internacionales impugnados (tratado y protocolo de extradición entre México y España; y la Convención de Genocidio); 4. no se concede amparo contra el Acuerdo de la SRE en lo que corresponde al delito de genocidio, así como contra la ejecución atribuida a la PGR y el Reclusorio; y 5. no se concede amparo contra el Acuerdo de la SRE en lo que corresponde al delito de terrorismo, así como contra la ejecución atribuida a la PGR y el Reclusorio. ${ }^{87}$

86 Siqueiros, José Luis, "La extradición y la jurisdicción universal. El caso Cavallo", Revista de Derecho Privado, México, nueva serie, nueva época, año III, núm. 7, enero-abril de 2004, p. 117.

87 Idem, p. 128. "Los rubros de las tesis aprobadas por el Pleno fueron las siguientes: 1) Extradición. El tratado internacional del 21 de noviembre de 1978 celebrado por los Estados Unidos Mexicanos y el Reino de España y su protocolo modificatorio, no violan los artículos 16 y 19 constitucionales (tesis I/2003). 2) Genocidio. No es delito político (tesis II/2003). 3) Extradición. No debe analizarse la competencia de las autoridades jurisdiccionales del Estado requirente en el procedimiento a que se refiere el tratado de extradición y asistencia mutua en materia penal celebrado entre México y el Reino de 
La postura de la SCJN mexicana se reduce a los siguientes puntos: 1. los delitos de genocidio y terrorismo no son delitos políticos (el genocidio tutela la existencia de grupos humanos; no se violenta el artículo 15 constitucional que prohíbe la extradición de reos políticos; el genocidio es un ilícito contra la humanidad; el terrorismo no es delito político por ser un ilícito contra la seguridad nacional y de las personas); 2 . en virtud del Tratado y Protocolo de extradición entre México y España, no se analiza la competencia del tribunal del país requirente (no se analiza la competencia de España por respeto a su soberanía; contra esta postura emitió un voto particular el ministro Humberto Román Palacios, con

España el 21 de noviembre de 1978 (tesis III/2003). 4) Terrorismo, no es delito político (tesis IV/2003)"; Suprema Corte de Justicia de la Nación, amparo en revisión 140/2002, en los puntos resolutivos: Primero. Se modifica la sentencia recurrida. Segundo. Se confirma el amparo concedido por el juez de Distrito a Ricardo Miguel Cavallo en contra del acuerdo de dos de febrero de dos mil uno, emitido por el secretario de Relaciones Exteriores, en lo que corresponde al delito de tortura por encontrarse prescrito, así como su ejecución atribuida al propio secretario de Estado, al procurador general de la República y al director del Reclusorio Preventivo Varonil Oriente del Distrito Federal, en virtud de haber resultado infundados los agravios expuestos al respecto por el secretario de Relaciones Exteriores y el agente del Ministerio Público de la Federación. Tercero. Conforme a la precisión indicada en el considerando sexto de la presente resolución, la Justicia de la Unión no ampara ni protege a Ricardo Miguel Cavallo, contra los actos que reclamó del presidente de la República, Cámara de Senadores, secretario de Relaciones Exteriores, subprocurador jurídico de la Procuraduría General de la República y secretario de Gobernación, que hizo consistir en el proceso de creación (celebración y aprobación) del Tratado de Extradición y Asistencia Mutua en Materia Penal entre los Estados Unidos Mexicanos y el Reino de España de veintiuno de noviembre de mil novecientos setenta y ocho, publicado en el Diario Oficial de la Federación el veintiuno de mayo de mil novecientos ochenta, el protocolo de veintitrés de junio de mil novecientos noventa y cinco, publicado en el Diario Oficial de la Federación el diecinueve de marzo de mil novecientos noventa y siete, por medio del cual se modificó el Tratado de Extradición indicado y el Convenio para la Prevención y la Sanción del Delito de Genocidio, de nueve de diciembre de mil novecientos cuarenta y ocho. Cuarto. La Justicia de la Unión no ampara ni protege a Ricardo Miguel Cavallo en contra del acuerdo de dos de febrero de dos mil uno, emitido por el secretario de Relaciones Exteriores, en lo que corresponde al delito de genocidio, así como su ejecución atribuida al propio secretario de Estado, al procurador general de la República y al director del Reclusorio Preventivo Varonil Oriente del Distrito Federal. Quinto. La Justicia de la Unión no ampara ni protege a Ricardo Miguel Cavallo en contra del acuerdo de dos de febrero de dos mil uno, emitido por el secretario de Relaciones Exteriores, en lo que corresponde al delito de terrorismo, así como su ejecución atribuida al propio secretario de Estado, al procurador general de la República y al director del Reclusorio Preventivo Varonil Oriente del Distrito Federal. 
base en la Ley de Extradición Internacional (Ley de Extradición) mexicana; los ministros Sergio Salvador Aguirre Anguiano, José de Jesús Gudiño Pelayo y Juan Díaz Romero emitieron un voto minoritario en el sentido de que el genocidio sólo podría ser juzgado o por un tribunal argentino o por la CPI; el fiscal español anticorrupción declaró que la SCJN mexicana perdió la oportunidad de declarar cabalmente la jurisdicción universal); 3. prescripción del delito de tortura (basándose en derecho interno, no procede la acumulación de delitos, por lo que la prescripción se estudia independientemente, en virtud de lo cual el delito de tortura se considera prescrito; es decir, la Corte olvidó sentencias célebres en derecho internacional). ${ }^{88}$

La SCJN analiza el delito de genocidio en el considerando décimo primero. Determina que el juez de Distrito estuvo en lo correcto al señalar que la Convención de Genocidio no contradice el artículo 15 de la Constitución mexicana (prohibición de extradición de reos políticos), en virtud de que el genocidio no es un delito político. Un delito político - expresa la SCJN_ "debe entenderse como aquel que se comete en contra del Estado". Además — señala la SCJN- existen la teoría objetiva y subjetiva de clasificación de los delitos políticos. En la teoría objetiva de los delitos políticos "se sostiene que la cualidad de político debe referirse de modo claro a la naturaleza del bien jurídico o interés legítimo que mediante el tipo delictivo se pretende tutelar". La teoría subjetiva del delito político "se apoya en la idea de que los delitos políticos son aquellos en los que su autor, independientemente del bien jurídico violado o puesto en peligro, haya realizado la conducta típica con la intención de menoscabar la integridad jurídica del Estado o regular el funcionamiento de sus instituciones". Respecto del artículo II de la Convención de Genocidio, la SCJN establece que:

Por genocidio debe entenderse cualquiera de los actos perpetrados con la intención de destruir total o parcialmente a un grupo nacional, étnico, racial o religioso, describiéndose como tal la matanza de miembros del grupo; lesionar gravemente a la integridad física o mental de los miembros del grupo; sometimiento intencional del grupo a condiciones de existencia que hayan de acarrear su destrucción física, total o parcial; las medidas 
destinadas a impedir los nacimientos en el seno del grupo y el traslado por la fuerza de niños del grupo a otro grupo.

... la finalidad del delito de genocidio es la protección de la existencia de determinados grupos humanos considerados estables, que constituyen el ámbito en el que se desarrolla el individuo en prácticamente todas las facetas sociales y culturales de su existencia y que forman el sustrato de la comunidad internacional siendo, en relación a su funcionalidad para el individuo, de importancia casi comparable a los propios Estados.

La SCJN adopta la tesis de que el tipo penal de genocidio protege a ciertos grupos humanos considerados estables (según Schabas, lo que realmente se protege en el tipo penal de genocidio son las "minorías nacionales", noción surgida después de la PGM). La SCJN también analiza que el móvil no es relevante para determinar la existencia de genocidio, sino que es necesaria la intención de destruir total o parcialmente a los grupos protegidos por la Convención de Genocidio (nacional, racial, étnico y religioso). ${ }^{89}$ Esto implica que se protege no al individuo como tal, sino al grupo como colectividad. ${ }^{90}$

Por otra parte, la SCJN determinó que en virtud de la legislación española y mexicana vigente en la fecha en que ocurrieron los hechos, el genocidio no ha prescrito (tampoco el de terrorismo). Es decir, no ha pasado el tiempo necesario para declarar prescrito el delito internacional de genocidio, lo cual implica que dicho crimen está sujeto a prescripción — conforme a la resolución de la $\mathrm{SCJN}$ — ${ }^{91}$ En el considerando décimo

89 Amparo en revisión 140/2002, "Para nuestro estudio resulta relevante precisar que la serie de conductas que enumera el artículo II de la Convención impugnada es necesario que sean cometidas con la intención de destruir total o parcialmente a un grupo nacional, racial, étnico o religioso, debiendo distinguirse que esa intención de destruir a un grupo, no se trata del móvil del delito, sino del elemento subjetivo del injusto, lo que se traduce en que el móvil con el que se actúe es irrelevante para la existencia del delito, ya que se puede actuar con el propósito de destruir al grupo por motivos políticos, económicos, por venganza u otros, es decir, para la configuración del delito de genocidio, no es necesario conocer las razones o móvil de la intención de destruir a un grupo".

90 Idem, "... debe concluirse que el delito de genocidio protege la existencia de determinados grupos humanos, es decir, se trata de un bien jurídico supraindividual, cuyo titular no es la persona física sino el grupo como colectividad".

91 Idem, "En el considerando décimo tercero se analizan los agravios relativos a la prescripción de las acciones penales de los delitos de genocidio, terrorismo y tortura, arribándose a la conclusión de que el primero y segundo de ellos no han prescrito, porque conforme a la legislación española prescribían en un término de veinte años, mientras 
cuarto, la SCJN también determina que los delitos de genocidio y terrorismo no pueden considerarse delitos militares. La defensa de Cavallo argumentó que los delitos que le son imputados son de índole militar; asimismo, argumentó que la Constitución mexicana, y que el Tratado de Extradición y Protocolo Adicional convenidos por México y España, proscriben la extradición en tratándose de delitos de orden militar. La defensa de Cavallo argumentó que en virtud de sus actividades en la Escuela Superior de Mecánica de la Armada (ESMA), aquél ejercía actividades que reconocen la jerarquía militar.

La SCJN estimó correcto el argumento del juez de Distrito en el sentido de que las conductas atribuidas a Cavallo no lesionan un bien jurídico militar, en virtud de que al servicio de la disciplina militar se "había afectado a la humanidad". ${ }^{92}$ Además, conforme a legislación y doctrina internacional, la obediencia debida no es excluyente de responsabilidad en tratándose de crímenes contra la humanidad. Por otra parte, no es excluyente de responsabilidad actuar bajo órdenes superiores o argumentar circunstancias especiales tales como: 1 . el estado de guerra; 2 . inestabilidad política interna; o, 3. cualquier otra emergencia política. Además, las conductas imputadas se dirigieron contra opositores al régimen militar, es decir, contra la población civil que se oponía al régimen dictatorial, por lo que no puede afirmarse que se haya lesionado un bien jurídico militar. Delito militar es "toda acción típica imputable, culpable y punible, cuya antijuridicidad se caracteriza por la lesión o puesta en peligro de un bien jurídico militar o tutelado por fuerzas armadas en cumplimiento de su misión constitucional". Respecto del delito de terrorismo, la SCJN determinó — conforme a la legislación internacional - que es un delito común de trascendencia internacional cualquiera sea su móvil. Por otra parte, la defensa de Cavallo argumentó que por decisión soberana de Argentina, dicho país otorgó amnistía mediante las leyes de Obediencia Debida y de Punto Final, motivo por el cual ha sido absuelto y no se le

que en la legislación mexicana prescribían en treinta y veintiún años, respectivamente, y de la fecha en que cesaron los delitos de genocidio y terrorismo en marzo de mil novecientos ochenta y tres a la fecha de aprehensión del inculpado, agosto de dos mil, no han transcurrido los términos prescriptorios indicados".

92 Becerra Ramírez, Manuel, op. cit., nota 93, p. 610, considera que muy trascendente calificar el delito de genocidio como ilícito contra la humanidad, porque implica reconocer el derecho imperativo internacional, es decir, la existencia de una jerarquía en el derecho internacional. 
puede juzgar dos veces por el mismo delito. Además de que en Argentina ya habían sido sancionados los verdaderos culpables. La SCJN consideró correctas las argumentaciones del juez de Distrito en el sentido de que las leyes de Obediencia Debida y Punto Final no eran aplicables al caso, en virtud de que si Argentina decidió no ejercer su jurisdicción para perseguir delitos internacionales, "no impedía que cualquier otro Estado del concierto mundial, pudiera hacer valer su propia jurisdicción, porque los tratados internacionales aplicables al caso concreto reconocían a cualquier Estado parte en los mismos, jurisdicción para perseguirlos... con el afán de prevenir su impunidad". Además, dichas leyes no son vinculatorias para los demás Estados (extraterritorialmente). Conforme a la jurisprudencia de la Corte Interamericana de Derechos Humanos (CIDH, caso "Barrios Altos") no se puede otorgar amnistía que tienda a impedir la sanción de los responsables de violaciones graves a los derechos humanos. Dichas leyes — argumentó el juez de Distrito- son contrarias a la obligación internacional (a las "normas imperativas de carácter internacional", es decir, normas de carácter ius cogens) de los Estados de asegurar el enjuiciamiento o castigo de las personas responsables de los crímenes de guerra y lesa humanidad. No opera la inmunidad o amnistía a persona alguna por los delitos de genocidio y terrorismo. Es decir, las leyes de Obediencia Debida y Punto Final se oponen a las obligaciones internacionales, por lo que no podían ser reconocidas por el Estado mexicano. Y por si no fuera poco, el juez de Distrito señaló que dichas leyes fueron derogadas. ${ }^{93}$

Por otra parte, la SCJN consideró correcto el argumento del juez de Distrito en el sentido de que el hecho de que ciertos individuos hubiesen sido juzgados en la Argentina, no "era suficiente para que los restantes quedaran excluidos de la responsabilidad que legalmente cada uno le correspondía, porque los efectos de una sentencia no eran erga omnes" y no puede constituir verdad legal o cosa juzgada para terceros ajenos a los

93 Pedro, Hugo Alberto de, "Nulidad efectiva de las leyes del olvido", Equipo Nizkor, http://www.derechos.org/nizkor/arg/doc/nulid2.html, consultado en junio de 2008. "Las Leyes de Punto Final y Obediencia Debida fueron derogadas por el Congreso Nacional el 25 de marzo de 1998 por la Ley 24.952”. Por otra parte, el 14 de junio de 2005, la Suprema Corte de Justicia de la Nación argentina declaró la nulidad de las leyes de Obediencia Debida y Punto Final. Puede consultarse el texto completo de la resolución en http://www.derechos.org/nizkor/arg/doc/nulidad.html, consultada en noviembre de 2006. 
procedimientos mencionados; es decir, "la cosa juzgada derivada de sentencia dictada a favor o en contra de una persona distinta no podía beneficiar al quejoso". Por otro lado, la SCJN determinó que de las constancias de los autos no se desprende que con la extradición de Cavallo a España se le impondrían penas trascendentales (prohibidas en el artículo 22 de la Constitución mexicana) o se fuera a agravar su situación jurídica, en virtud de una supuesta fobia de los españoles contra los militares argentinos miembros de la ESMA. Cabe señalar que la defensa de Cavallo argumentó que con su extradición se le impondrían penas trascendentales y se agravaría su situación jurídica en virtud de una fobia de los españoles contra los militares argentinos de la ESMA. Además, de las constancias no se desprende que Cavallo fuese requerido por un tribunal especial constituido especialmente para juzgarlo; tampoco las leyes en las que se funda su enjuiciamiento fueron creadas ex-profeso. La SCJN determinó que en caso de ser extraditado, Cavallo sería enjuiciado por un tribunal previamente establecido y conforme a leyes existentes antes de ocurridos los hechos. Cavallo tendría entonces la posibilidad de defenderse ante los tribunales. La valoración de la doctrina en México respecto de la resolución de la $\mathrm{SCJN}$ sobre el Caso Cavallo es prácticamente unánime en el sentido de que dicha resolución reafirma la vigencia del principio de jurisdicción universal. ${ }^{94}$ Por otro lado, la sentencia de la SCJN sobre el caso Cavallo confirma la jerarquía de los tratados internacionales sobre las leyes nacionales (Becerra y Siqueiros), y se asienta la facultad de control de la SCJN sobre la política exterior mexicana (Becerra). La SCJN también reconoce el principio de jurisdicción implícita en la Convención de Genocidio (Siqueiros). A juicio de Becerra, la resolución de la SCJN sobre el Caso Cavallo, es "la expresión de la opinio juris de México" y —agrega — "es un eslabón muy importante en el camino de la creación de un Estado de derecho internacional que evite la impunidad de los crímenes de lesa humanidad". En suma, la SCJN resolvió favorablemente la extradición de Cavallo a España para ser juzgado por los delitos de genocidio y terrorismo, pero no por el de tortura, por considerar que este último ha prescrito.

94 Becerra Ramírez, Manuel, op. cit., nota 93, pp. 625 y 626; Díaz Müller, Luis T., "Globalización y derechos humanos: el orden del caos", en Díaz Müller, Luis T. (coord.), Globalización y derechos humanos, México, UNAM, Instituto de Investigaciones Jurídicas, 2003, p. 42; Siqueiros, José Luis, op. cit., nota 94, pp. 128-130. 
El 28 de junio de 2003 fue trasladado a España para ser juzgado por los delitos de genocidio y terrorismo. El 28 de diciembre de 2006, un juez argentino (Sergio Torres) pide a España la extradición de Cavallo, acusado de "detenciones ilegales, torturas, extorsión, robos con violencia, intimidación y falsificación documental, todos delitos cometidos durante la dictadura militar". ${ }^{95}$ La solicitud del juez Torres fue aceptada por Cavallo el 19 de febrero de 2007. ${ }^{96}$ El 14 de marzo de 2008, España autoriza la reextradición de Cavallo a la República Argentina, previa autorización del gobierno mexicano. ${ }^{97} \mathrm{El}$ argumento de peso para la justicia española reside en "la absoluta prioridad del fuero del lugar de comisión de los hechos y la necesaria unidad en el enjuiciamiento de otros procesados llevan a consentir la entrega extradicional que una vez materializada determinará el sobreseimiento y archivo del presente sumario". ${ }^{8}$ Cabe señalar que entre las acusaciones contra Cavallo en la República Argentina (detenciones ilegales, torturas, extorsión, robos con violencia, intimidación y falsificación documental), no figura el delito de genocidio, pero sí encuadran en el tipo penal de crímenes contra la humanidad. Por el momento no existen datos suficientes como para evaluar el procesamiento contra Cavallo en Argentina, pero sí es importante señalar que la justicia argentina condenó a "reclusión perpetua e inhabilitación absoluta perpetua" a Miguel Osvaldo Etchecolatz por homicidio calificado; privación ilegal de la libertad calificada y aplicación de tormentos, "todos estos, delitos de lesa humanidad cometidos en el marco del genocidio

95 Archivo de Prensa del Gobierno de Mendoza, Argentina, "España extraditará al represor Cavallo", http://www.earchivo.mendoza.gov.ar/todo.php?idnota $=40582$, nota fechada el 1 de marzo de 2008, consultada en junio 2008.

96 Castro, Aída, "Cronología del caso Cavallo", El Universal, 29 de febrero de 2008, http://www.eluniversal.com.mx/notas/486345.html, consultado en junio de 2008.

97 Decreto de Promulgación del Tratado de Extradición y Asistencia Mutua en Materia Penal, entre los Estados Unidos Mexicanos y el Reino de España, firmado en México, el 21 de noviembre de 1978, Diario Oficial de la Federación, 21 de mayo de 1980, http://www.ordenjuridico.gob.mx/TratInt/Penal/ESP1.pdf, consultado en junio de 2008, “Artículo 18. Salvo en el caso previsto en el párrafo b) del apartado 1o. del artículo 17 la reextradición en beneficio de un tercer Estado no será otorgada sin el consentimiento de la parte que ha concedido la extradición. Esta podrá exigir el envío previo de la documentación prevista en el artículo 15, así como un acta que contenga la declaración razonada del reclamado sobre si acepta la reextradición o se opone a ella".

98 Equipo Nizkor, "Texto completo del auto en el que se resuelve el sobreseimiento y el archivo de la causa Cavallo", http://www.derechos.org/nizkor/espana/juicioral/ doc/archivo1.html, consultado en junio de 2008. 
que tuvo lugar en la República Argentina entre los años 1976 y 1983". 99 Es decir, nada impide que la justicia argentina condene a Cavallo por delitos de lesa humanidad cometidos en el marco del genocidio ocurrido durante la dictadura argentina.

\section{EL CASO "LOS HALCONES"}

En junio de 2002, el Comité 68 Pro-Libertades Democráticas A. C. interpone denuncia ante la Fiscalía Especializada para Movimientos Sociales y Políticos del Pasado (Femospp) contra Luis Echeverría y otros por el delito de genocidio. La Femospp, habiendo agotado la averiguación previa, el 22 de julio de 2004 ejerce la acción penal contra el ex presidente Luis Echeverría Álvarez, el ex secretario de Gobernación, Mario Augusto José Moya Palencia, ${ }^{100}$ así como contra importantes jefes de policía y miembros del grupo paramilitar conocido como "Los Halcones" (total: 11 personas inculpadas por la Femospp). Se les atribuyó presunta responsabilidad por el delito de genocidio, tipificado en el artículo 149 bis del Código Penal para el Distrito y Territorios Federales en Materia de Fuero Común y para toda la República en materia de Fuero Federal (Código Penal Federal), vigente en 1971. ${ }^{101}$

El asunto se substanció ante el Juzgado Segundo de Distrito de Procesos Penales Federales en el Distrito Federal (Juzgado de Distrito), expediente 114/2004. Dicho Juzgado de Distrito resuelve el sobreseimiento de la causa penal en virtud de lo que consideró prescrito el delito de genocidio. El Ministerio Público Federal apela dicha resolución ante el Quinto Tribunal Unitario en Materia Penal del Primer Circuito (toca 415/2004), pero a solicitud del procurador general de la República, la SCJN mexicana atrae el caso por unanimidad el 13 de octubre de 2004, al verse reunidos los requisitos formales de la fracción III del artículo

99 "Veredicto contra Etchecolatz por crímenes contra la humanidad", Equipo Nizkor, http://www.derechos.org/nizkor/arg/ley/veredicto.html, consultado en junio de 2008.

100 Murió el 9 de octubre de 2006. El Universal, 10 de octubre de 2006. http://www. eluniversal.com.mx/nacion/144058.html.

101 Corzo Sosa, Edgar, "Genocidio, imprescriptibilidad y retroactividad (comentario a la sentencia del recurso de apelación 1/2004-PS)", Cuestiones Constitucionales, núm. 14, enero-junio de 2006, p. 229. Este comentario jurisprudencial puede consultarse en http://www.juridicas.unam.mx/publica/librev/rev/cconst/cont/14/cj/cj9.pdf. 
105 de la Constitución mexicana, turnando el asunto a la Primera Sala (expediente 1/2004-PS).

El 23 de febrero de 2005, la SCJN rechazó el proyecto del ministro Juan Silva Meza. Este proyecto determinaba que el delito de genocidio es imprescriptible no importa el tiempo en que haya sido cometido, en virtud de que la declaración interpretativa hecha por México, a la Convención sobre la Imprescriptibilidad ${ }^{102}$ de 1968, no obliga al Estado mexicano, toda vez que violenta el objeto y fin de dicha Convención. El objeto y fin de la Convención sobre Imprescriptibilidad es - como su nombre lo indica - reafirmar el principio de la imprescriptibilidad de diversos delitos de tal gravedad (como lo es el de genocidio), que por su naturaleza son imprescriptibles. ${ }^{103}$

Cabe señalar que el 10 de diciembre de 2001, el Senado de la República mexicana realiza una declaración interpretativa ${ }^{104}$ a la Convención

102 Publicada en el Diario Oficial de la Federación el 22 de abril de 2002. La ratificación fue firmada por el presidente de la República mexicana el 12 de febrero de 2002 y depositada (con la declaración interpretativa hecha por el Senado mexicano el 10 de diciembre de 2001) en la Organización de las Naciones Unidas el 15 de marzo de 2002. Véase www.ordenjuridico.gob.mx.

103 Quizá sea importante señalar que existe un "Auto por el que se informa a la Fiscalía de la Corona sobre la imprescriptibilidad de las conductas imputadas a Augusto Pinochet", emitido por Baltasar Garzón Real, magistrado-juez del Juzgado Central de Instrucción número cinco de la Audiencia Nacional, el 18 de diciembre de 1998, que ordena cursar comunicación urgente al Crown Prosecutor Service para poner en su conocimiento esta resolución y el auto de procesamiento que se remitirán a través del Ministerio de Justicia por los cauces diplomáticos correspondientes, en la cual se señala por qué el delito de genocidio (terrorismo y tortura) no ha prescrito. Los delitos contra la humanidad (incluye el de genocidio) no prescriben: 1) Debido a su naturaleza (protección de derechos humanos); 2) porque la Convención sobre Imprescriptibilidad entró en vigor el 11 de noviembre de 1970 , pero sólo reafirma un principio reconocido por la comunidad internacional y por la práctica internacional (casos Klaus Barbie, Pierbke, etcétera). Véase http://www.derechos.org/nizkor/chile/juicio/18dic98.htm, consultado en noviembre de 2008.

104 "Para precisar la postura del Estado mexicano, en el caso particular, sin que implique exclusión ni modificación de los efectos legales que se persiguen con la Convención, si ésta es aprobada por el Senado de la República, el Ejecutivo Federal procedería al depósito del instrumento de ratificación respectivo ante la Organización de los Estados Americanos, con la siguiente: DeClaracion InTERPRETATIVA 'Con fundamento en el artículo 14 de la Constitución Política de los Estados Unidos Mexicanos, el Gobierno de México, al ratificar la Convención sobre la Imprescriptibilidad de los Crímenes de Guerra y de los Crímenes de Lesa Humanidad, adoptada por la Asamblea General de las Na- 
sobre Imprescriptibilidad en el sentido de que se entenderán imprescriptibles los delitos que consagra dicha Convención, pero que hayan sido cometidos con posterioridad a su entrada en vigor en México. ${ }^{105}$ El 15 de marzo de 2002, México deposita la ratificación en la Secretaría General de ONU, incluyendo la declaración interpretativa citada. ${ }^{106}$ El 15 de junio de 2005, la SCJN resuelve el resto de los agravios. ${ }^{107}$ Postula la prescripción parcial del delito de genocidio, al declarar que dicho delito no prescribe para el ex presidente Echeverría y el ex secretario de Gobernación, Moya Palencia, pero sí para los otros inculpados. Es decir, se atenúa la postura del proyecto del ministro Silva Meza, proyecto que adoptaba la imprescriptibilidad del delito de genocidio no importa el tiempo en que haya sido cometido, lo cual es lo correcto desde el punto de vista internacional. La SCJN también resuelve devolver los autos al Tribunal Unitario en Materia Penal del Primer Circuito del Distrito Federal (Tribunal Unitario) para los efectos de que determine si se reúnen los requisitos establecidos en el artículo 16 de la Constitución mexicana respecto al cuerpo del delito y la probable responsabilidad. La SCJN argumenta que la Declaración Interpretativa realizada por México (por el Senado de la República) es en realidad una reserva, toda vez que modifica los efec-

ciones Unidas el 26 de noviembre de 1968, entenderá que únicamente considerará imprescriptibles los crímenes que consagra la Convención, cometidos con posterioridad a su entrada en vigor para México"'. Gaceta Parlamentaria del Senado de la República, 10 de diciembre de 2001, www.senado.gob.mx.

105 Corzo Sosa, op. cit., nota 109, p. 230.

106 Silva García, Fernando, "El caso Echeverría: ¿prohibición de genocidio versus irretroactividad de la ley?", Cuestiones Constitucionales, núm. 14, enero-junio de 2006, p. 241. "La Convención adoptada en México en el año de 2002 prevé que es imprescriptible el crimen de genocidio cualquiera que sea la fecha en que se hayan cometido. Dicho tratado fue limitado en su eficacia por la Cámara de Senadores, mediante una declaración en la que se expuso que sólo serían imprescriptibles los crímenes cometidos con posterioridad a la entrada en vigor de dicho tratado en México, con base en el principio constitucional de irretroactividad de la ley (artículo 14 constitucional)".

107 Ibidem, p. 241. Este autor señala: "El 15 de junio de 2005, por cuatro votos contra uno, la 1a. Sala de la SCJN resolvió, entre otras cosas, que en México no es posible condenar el posible asesinato gubernamental de un grupo de individuos, por razones políticas o ideológicas, si se verificó antes del año de 2002, en que se adoptó la Convención sobre Imprescriptibilidad del Genocidio [sic] y si las acciones dirigidas a que sea reparado se intentan después de 30 años del suceso". 
tos jurídicos de la Convención sobre Imprescriptibilidad. ${ }^{108}$ Por su parte, el Tribunal Unitario, al resolver el caso, declara que el grupo de estudiantes agredidos por el grupo llamado "Los Halcones" no tiene calidad de grupo pasivo del delito de genocidio (grupo nacional, étnico, racial, o religioso) y que el delito que aparece en autos es el de homicidio, el cual ha prescrito, por lo que decreta el sobreseimiento de la causa penal y archivar el expediente.

El Código Penal Federal tipifica solamente el tipo penal de genocidio y no el de crimen de lesa humanidad (también, "crímenes contra la humanidad"), por lo que el Tribunal Unitario no debió sobreseer el la causa penal por el tipo penal de genocidio, el cual es imprescriptible no importa el tiempo en que se haya cometido. En virtud de que en México la legislación secundaria no tipifica los crímenes contra la humanidad, y para evitar que queden impunes, estos delitos deben sancionarse conforme al tipo penal base de genocidio, algo con pleno respaldo en la doctrina internacional. El tipo penal de crímenes contra la humanidad fue definido desde el Tribunal de Nüremberg y codificado en los "Principios de Derecho Internacional reconocidos por el Estatuto y por las sentencias del Tribunal de Nüremberg", aprobado por la CDI y la Asamblea General de la ONU desde 1950. Es decir, aunque los hechos ocurridos tanto en Tlatelolco en 1968 y durante el 10 de junio de 1971, encuadren más bien dentro del tipo penal de crímenes contra la humanidad, deben sancionarse conforme al tipo penal de genocidio, el tipo penal base en México para sancionar tanto los crímenes contra la humanidad como el genocidio, los cuales son imprescriptibles y su sanción y prevención repre-

108 Corzo Sosa, op. cit., nota 109, p. 234. "En lo que a nosotros corresponde, debemos decir que además de la ambigüedad con que se trata el tema [por la SCJN], pues empieza señalando que la Declaración Interpretativa es una reserva, pero termina afirmando que no lo es, el hecho de que la Declaración Interpretativa reafirme la 'no retroactividad' del tratado, no significa que no cambie las disposiciones de la Convención". Por el contrario, si la Convención dice que se aplicará hacia el pasado y la declaración en cambio dice que sólo hacia el futuro, es obvio que hay una contradicción y alteración de la Convención. Lo que sucede es que con la Declaración se está queriendo volver a la normalidad de lo dispuesto en la Convención de Viena, en donde se prohíbe la retroactividad de los tratados internacionales. Sin embargo, se soslaya lo dispuesto en el artículo 28, en donde se sostiene que ello es posible si el tratado lo establece. En consecuencia, el regreso a la normalidad de Viena lo que está haciendo es hacer nugatorio el sistema de Viena, en donde se posibilita que un tratado tenga efectos retroactivos, como se sostuvo en la Convención sobre Imprescriptibilidad". 
sentan una norma de carácter ius cogens (artículo 53 y 64 de la Convención de Viena sobre el Derecho de los Tratados de 1969). ${ }^{109}$ La SCJN, al desconocer la imprescriptibilidad de los crímenes de lesa humanidad y genocidio, debilita el sistema democrático mexicano y en especial al Poder Judicial mismo. ${ }^{110}$ Es importante recordar que no solamente existe la globalización económica, sino también la universalización de los derechos humanos (DH). Además, la Convención de Genocidio debe respetarse, aún a pesar de que no exista un acuerdo convencional que obligue al Estado. Así lo estableció la jurisprudencia de la CIJ en su opinión consultiva de 1951, emitida a raíz de una resolución de la Asamblea General de la ONU del 16 de noviembre de 1950, mediante la cual se solicitó a la CIJ que pronunciara una opinión consultiva que responda lo siguiente: si un Estado que hace una reserva a la Convención de Genocidio, sigue siendo o no parte de la Convención, y en caso afirmativo, qué relación tiene el Estado que hace la reserva con aquel Estado o aquellos Estados que objetan dicha reserva, y qué relación tiene el Estado que realiza la reserva con el Estado o los Estados que aceptan dicha reserva a la Convención. Además, se cuestiona a la CIJ qué efectos legales se producen si la objeción a la reserva es hecha por un Estado signatario de la convención, pero que no la ha ratificado y con otro Estado que puede firmarla o acceder a la misma, pero no lo ha hecho. La CIJ consideró que el Estado que realiza una reserva a la Convención de Genocidio, sí puede ser considerado como parte de la misma en el caso de que dicha reserva sea compatible con el objeto y propósito de la citada Convención. Lo relevante de la Opinión Consultiva de la CIJ es que señala que la CSG tiene características especiales y que los "principios que subyacen en la Convención son reconocidos por las naciones civilizadas como obligatorios para los Estados aun sin existir ninguna obligación convencional". Agrega que el propósito de la Convención de Genocidio es "humanitaria" y "civilizatoria" y que los Estados no tienen intereses individuales

109 Que la obligación de prevención y sanción del genocidio es una norma de carácter ius cogens lo demuestra Antonio Gómez-Robledo en su libro El ius cogens internacional. Estudio histórico-crítico, 2a. ed., México, UNAM, Instituto de Investigaciones Jurídicas, 2003.

110 Becerra Ramírez, Manuel, op. cit., nota 15, p. 206. Este comentario jurisprudencial se puede consultar en http://www.juridicas.unam.mx/publica/librev/rev/cconst/cont/ $14 / c j / c j 8 . p d f$. 
en este respecto, sino un interés común. ${ }^{111}$ En parte, esto nos lleva a concluir que la SCJN no tomó en consideración el derecho internacional en su resolución sobre "Los Halcones". La SCJN soslayó la consideración del derecho internacional. ${ }^{12}$ Por otra parte, es importante comentar que el proyecto del ministro Silva Meza (del 23 de febrero de 2005) pone a debate los siguientes puntos: 1. el Estado mexicano debe ceñirse al Estado al derecho, algo que no existía en la época en que se cometió el delito; 2. el Estado está sometido igualmente al derecho internacional de los derechos humanos; 3. la costumbre internacional también contiene obligaciones en materia de derechos humanos; 4. los delitos de lesa humanidad, según la definición del Estatuto del Tribunal de Nüremberg, son imprescriptibles; 5. la declaración interpretativa realizada por México a la Convención sobre Imprescriptibilidad no es obligatoria, en virtud de que contradice su objeto y fin (conforme a los artículos 11 y 18 de la Convención de Viena de 1969); 6. el principio de irretroactividad no aplica a

111 Reservations to the Convention the Prevention and Punishment of the Crime of Genocide, Advisory Opinion of May 28th, 1951, http://www.icj-cij.org/docket/files/12/ 4283.pdf, consultada en junio de 2008. "The solution of these problems must be found in the special characteristics of the Genocide Convention. The origins and character of that Convention, the objects pursued by the General Assembly and the contracting parties, the relations which exist between the provisions of the Convention, inter se, and between those provisions and these objects, furnish elements of interpretation of the will of the General Assembly and the parties. The origins of the Convention show that it was the intention of the United Nations to condemn and punish genocide as "a crime under international law" involving a denial of the right of existence of entire human groups, a denial which shocks the conscience of mankind and results in great losses to humanity, and which is contrary to moral law and to the spirit and aims of the United Nations (Resolution 96 (1) of the General Assembly, December 11th. 1946). The first consequence arising from this conception is that the principles underlying the Convention are principles which are recognized by civilized nations as binding on States, even without any conventional obligation. A second consequence is the universal character both of the condemnation of genocide and of the co-operation required "in order to liberate mankind from such an odious scourge" (Preamble to the Convention). The Genocide Convention was therefore intended by the General Assembly and by the contracting parties to be definitely universal in scope. It was in fact approved on December 9th, 1948, by a resolution which was unanimously adopted by fifty-six States". Véase también los casos de la CIJ Barcelona Traction (1970), Nicaragua vs. Estados Unidos (1986), y Legalidad o Uso de Armas Nucleares (1993-1994).

112 Becerra Ramírez, Manuel, op. cit., nota 15, p. 207. "Se dejó escapar una oportunidad histórica con la cual se iba a reconocer la aplicación del derecho internacional de los derechos humanos en nuestro país". 
la Convención sobre Imprescriptibilidad, es decir, por voluntad soberana de los Estados, ese principio no aplica al delito de genocidio, y 7. el delito de genocidio es imprescriptible no importa el tiempo en que se haya cometido. ${ }^{113} \mathrm{La}$ demanda fundamental del movimiento estudiantil agredido en 1971 era la de poner en vigor el Estado de derecho. Respecto al Estado de derecho, es menester señalar que la Corte Interamericana de Derechos Humanos (Corte IDH), al pronunciarse sobre la denegación de justicia, señala que ésta significa tanto la inexistencia de un recurso efectivo, lo que se traduce en la violación de la Convención Interamericana de Derechos Humanos de 1969 (Convención Interamericana), como la ausencia de la independencia del Poder Judicial, es decir, podría argumentarse también la falta de independencia del Poder Judicial respecto del Poder Ejecutivo mexicanos en $1971 .{ }^{114}$ El advenimiento al poder de un gobierno democrático se traduce en un deber moral, político y legal de juzgar los delitos cometidos por el anterior régimen, es decir, existe la obligación (moral, política y legal) de perseguir a los violadores de derechos humanos (Becerra). En este sentido, ¿debe el Poder Judicial tomar en consideración el contexto político o simplemente debe aplicar la ley tal cual es? Como el sistema de los derechos humanos en un Estado democrático se cierra a través de fuentes internas e internacionales, la SCJN debió tomar en cuenta no solamente las fuentes internas. Además, el orden público internacional está constituido por: 1. el derecho internacional de los derechos humanos; 2. el derecho internacional humanitario; y 3. el derecho penal internacional. ${ }^{115}$ Por si no fuera poco, en el asunto

\section{Ibidem, pp. 208-210.}

114 Silva García, Fernando, op. cit., nota 114, pp. 245 y 246. “¿Es conforme a derecho (tutela judicial efectiva) considerar o contabilizar determinado plazo de prescripción en tiempos en que no existe acceso de las víctimas a los órdenes de justicia, en razón de la posición del sujeto activo del crimen de genocidio? Es, por ende, muy dudoso si el auto impugnado está debidamente justificado, debido a que el juez llega a la conclusión consistente en que el delito de genocidio ha prescrito, comenzando el cómputo respectivo a partir del 10 de junio de 1971, en que el acceso a los órganos de justicia es desde luego controlado por el sujeto activo del posible delito de genocidio, según las distintas manifestaciones históricas autorizadas, que constituyen un hecho notorio a efectos de la valoración judicial".

115 Becerra Ramírez, Manuel, op. cit., nota 15, p. 212. "Otro punto importante a tratar, para darle una interpretación adecuada al problema que se plantea es que la red bastante sólida y amplia del derecho internacional de los derechos humanos al que se le adiciona el derecho humanitario internacional y normas de derecho penal internacional, 
Barcelona Traction (1970), la CIJ declara que el delito de genocidio contiene normas obligatorias erga omnes, por lo que con relación a este delito (y otros de tal gravedad) los Estados tienen una obligación hacia la comunidad internacional, y no solamente frente a otros Estados. ${ }^{116}$ Esto implica que existe una jerarquía normativa en el ámbito internacional en la cual los derechos humanos adquieren especial importancia. Continuando con las ideas del ministro Silva Meza, podemos decir que la prohibición del delito de genocidio no depende de la existencia de un tratado, ya que la humanidad es la víctima, lo cual es afín a un principio de derecho internacional: la imprescriptibilidad del delito de genocidio y otros crímenes de gran gravedad. Esto significa que el principio de imprescriptibilidad del delito de genocidio no es nuevo y de alguna manera coincide con los argumentos vertidos por la CIJ en su opinión consultiva de 1951, en la cual señala que los Estados, en tratándose de un tratado que versa sobre la prohibición de genocidio, no tienen intereses particulares, sino un interés común, un interés de carácter colectivo o hacia la comunidad internacional. ${ }^{117}$

fundamentalmente a partir del fin de la Segunda Guerra Mundial, ha constituido una especie de orden público internacional compuesto de normas de una jerarquía superior por contener obligaciones erga omnes por obligar a todos los Estados y algunos de carácter imperativo, de ius cogens".

116 Cançado Trindade, Antonio Augusto, "Los derechos no susceptibles de suspensión en la jurisprudencia de la corte internacional de justicia. Primera parte", en Cançado Trindade, Antonio Augusto et al. (coords.), Estudios básicos de derechos humanos VI, Costa Rica, IIDH, 1996, p. 37. "En los famosos párrafos 33 y 34 del fallo, [Barcelona Traction, 1970] la Corte [internacional de Justicia] reconoció la existencia de obligaciones erga omnes, que 'conciernen a todos los Estados', es decir, 'obligaciones de los Estados respecto a la comunidad internacional en su conjunto'; tales obligaciones, agregó la Corte, 'se desprenden, por ejemplo en el derecho internacional contemporáneo, de la proscripción de los actos de agresión y de genocidio y también de los principios y de las normas relativas a los derechos fundamentales de la persona humana, incluida la protección contra la práctica de la esclavitud y la discriminación racial'”. Gómez-Robledo, Antonio, op. cit., nota 117, p. 61; García Ramírez, Sergio y Toro Huerta, "México y la Corte Interamericana de Derechos Humanos", en García Ramírez, Sergio (coord.), La jurisprudencia de la Corte Interamericana de Derechos Humanos, México, UNAM, Instituto de Investigaciones Jurídicas, 2001, p. 11; Odriozola Mariscal, Carlos Enrique, "Tratados y sucesión de Estados", Perspectivas del derecho en México, "Concurso Nacional de Ensayo Jurídico", México, UNAM, Instituto de Investigaciones Jurídicas, 2001, p. 20.

117 Reservations to the Convention..., cit., nota 119. 
El hecho de que la prohibición del delito de genocidio no depende de la existencia de un tratado, es decir, de una obligación convencional, más que debilitar las garantías individuales, las fortalece (Becerra). Esto implica también que el orden público internacional no depende de la nacionalidad, y que los derechos humanos reconocidos por el derecho internacional tienen una jerarquía superior en el orden jurídico interno. Así puede verse en las Constituciones de Argentina, ${ }^{118}$ Colombia, ${ }^{119}$ Guatemala ${ }^{120}$ y Rusia. ${ }^{121}$ Esto nos lleva de alguna manera al tema de la relación entre derecho interno y derecho internacional. La primacía del derecho

118 Artículo 75.22 de la Constitución de la Nación Argentina. "La Declaración Americana de los Derechos y Deberes del Hombre; la Declaración Universal de Derechos Humanos; la Convención Americana sobre Derechos Humanos; el Pacto Internacional de Derechos Económicos, Sociales y Culturales; el Pacto Internacional de Derechos Civiles y Políticos y su Protocolo Facultativo; la Convención sobre la Prevención y la Sanción del Delito de Genocidio; la Convención Internacional sobre la Eliminación de todas las Formas de Discriminación Racial; la Convención sobre la Eliminación de todas las Formas de Discriminación contra la Mujer; la Convención contra la Tortura y otros Tratos o Penas Crueles, Inhumanos o Degradantes; la Convención sobre los Derechos del Niño; en las condiciones de su vigencia, tienen jerarquía constitucional, no derogan artículo alguno de la primera parte de esta Constitución y deben entenderse complementarios de los derechos y garantías por ella reconocidos. Sólo podrán ser denunciados, en su caso, por el Poder Ejecutivo nacional, previa aprobación de las dos terceras partes de la totalidad de los miembros de cada Cámara. Los demás tratados y convenciones sobre derechos humanos, luego de ser aprobados por el Congreso, requerirán del voto de las dos terceras partes de la totalidad de los miembros de cada Cámara para gozar de la jerarquía constitucional", http://www.senado.gov.ar.

119 Artículo 93 de la Constitución Política de Colombia. "Los tratados y convenios internacionales ratificados por el Congreso, que reconocen los derechos humanos y que prohíben su limitación en los estados de excepción, prevalecen en el orden interno. Los derechos y deberes consagrados en esta Carta, se interpretarán de conformidad con los tratados internacionales sobre derechos humanos ratificados por Colombia", véase Constitución Política de Colombia, México, UNAM-FCE, 1994, pp. 22 y 23.

120 Artículo 46. "Preeminencia del Derecho Internacional. Se establece el principio general de que en materia de derechos humanos, los tratados y convenciones aceptados y ratificados por Guatemala, tienen preeminencia sobre el derecho interno". Constitución Política de la República de Guatemala, México, UNAM-FCE, 1994, p. 16. Puede consultarse en: http://www.bibliojuridica.org.

121 Artículo 15.4 de la Constitución de la Federación Rusa. "Los principios y las normas del derecho internacional y los acuerdos internacionales de la Federación Rusa son parte integrante de su sistema judicial. Si el acuerdo internacional de la Federación Rusa implica otras reglas que las previstas por la ley, se aplicarán las reglas del Tratado Internacional". Becerra Ramírez, Manuel, La Constitución rusa de 1993, México, UNAM, 1995, http://www.bibliojuridica.org. 
internacional público sobre el derecho interno "es clara y se evidencia por la regla general bien establecida de que un Estado no puede invocar las disposiciones de su derecho interno para disculpar la falta de cumplimiento de sus obligaciones internacionales, o para escapar a las consecuencias de ella". ${ }^{122}$ En caso de contradicción entre el derecho internacional y el derecho interno, en México, prevalece la Constitución, pero dicho país incurriría en responsabilidad internacional. ${ }^{123}$ La SCJN debió tomar en consideración la existencia del principio Pro Homine, el cual significa que la aplicación de los derechos humanos es flexible a favor de los individuos, es decir, el juzgador debe actualizar el derecho internacional con sus fallos y no violentarlo. Por otra parte, el delito de genocidio es punible en México (derecho interno) desde el 22 de octubre de 1952, fecha en la que entra en vigor en México la Convención de Genocidio de 1948. Lo que hace esta convención es codificar parte del derecho consuetudinario. La SCJN en la resolución sobre "Los Halcones" "hizo hincapié en la aplicación de los tratados internacionales, pero nunca se puso a discutir el carácter consuetudinario que tiene el crimen de genocidio y en consecuencia su imprescriptibilidad". ${ }^{124}$ Por su parte, la Convención sobre Imprescriptibilidad codifica el principio internacional sobre la imprescriptibilidad de los delitos de lesa humanidad (incluyendo el genocidio). Es decir, la imprescriptibilidad de los delitos de lesa humanidad - incluyendo la prohibición de genocidio- es un principio consuetudinario que debe ser respetado por el Estado mexicano, lo que in-

122 Sorensen, Max, Manual de derecho internacional público, México, FCE, 2002, pp. 65 y ss. "Un conflicto entre derecho internacional y derecho interno que surja ante la jurisdicción de un tribunal internacional se resuelve, por consiguiente, sobre la base de la supremacía del derecho internacional. Cuando surge en el ámbito del derecho interno u no se resuelve de la misma manera, la posición que se adopta es la de que hay una violación del derecho internacional y trae consigo las mismas consecuencias que cualquier otro acto ilegal. Por lo tanto, en cualquiera de los dos casos, se afirma la primacía del derecho internacional", p. 196.

123 Becerra Ramírez, Manuel, Panorama ..., op. cit., p. 10. "En caso de contradicción entre normas de derecho interno y el derecho internacional convencional prevalece la Constitución, pero el Estado incurre en responsabilidad internacional, a menos que se den las hipótesis señaladas en el artículo 46 de la Convención de Viena sobre el Derecho de los Tratados, en cuyo caso es justificable el incumplimiento". De este mismo autor puede consultarse también La recepción del derecho internacional en el derecho interno, México, UNAM, Instituto de Investigaciones Jurídicas, 2006.

124 Becerra Ramírez, Manuel, op. cit., nota 15, p. 216. 
cluye su poder judicial. En la resolución de la SCJN del 23 de febrero y del 15 de junio de 2005, se trata el tema de la declaración interpretativa hecha por el Senado a la Convención sobre Imprescriptibilidad para que ésta sea aplicable a los hechos ocurridos con posterioridad a su entrada en vigor. La SCJN consideró que en realidad se trataba de una "reserva" y no de una "declaración interpretativa", pero, si esto es así, el Senado mexicano está entonces violentando el objeto y fin de dicha Convención, es decir, está violando el derecho internacional y la obligación de México de respetar el objeto y fin de dicha Convención. Una declaración interpretativa tiene la función de crear un clima de mutua comprensión, pero no la de modificar las obligaciones contempladas en la misma. Una declaración interpretativa generalmente no obliga a las otras partes del tratado. Para ilustrar este argumento, veamos que la Convención del Mar de 1982, prohíbe las reservas pero permite las declaraciones interpretativas. ${ }^{125}$ El nuevo derecho del mar enseña que una declaración interpretativa tiene como finalidad armonizar el derecho interno con el internacional. Ahora bien, conforme al derecho de los tratados, una reserva a un tratado internacional, no debe violentar el objeto y fin del mismo. ${ }^{126}$ Esto implica que lo que México hizo referente a la Convención sobre Imprescriptibilidad fue en realidad una declaración interpretativa y no una re-

125 Artículos 309 y 310 de la Convención de las Naciones Unidas sobre el Derecho del Mar de 1982. "Artículo 309. Reservas y excepciones. No se podrán formular reservas ni excepciones a esta Convención, salvo las expresamente autorizadas por otros artículos de la Convención. Artículo 310 Declaraciones y manifestaciones. El artículo 309 no impedirá que un Estado, al firmar o ratificar esta convención o adherirse a ella, haga declaraciones o manifestaciones, cualquiera que sea su enunciado o denominación, a fin de, entre otras cosas, armonizar su derecho interno con las disposiciones de la Convención, siempre que tales declaraciones o manifestaciones no tengan por objeto excluir o modificar los efectos jurídicos de las disposiciones de la Convención en su aplicación a ese Estado", véase, Gómez-Robledo Verduzco, Alonso, El nuevo derecho del mar, guía introductoria a la Convención de Montego Bay, México, Porrúa-UNAM, 1986. Puede consultarse en http://www.bibliojuridica.org.

126 Convención de Viena sobre el Derecho de los Tratados: “Artículo 18. Un Estado deberá abstenerse de actos en virtud de los cuales se frustren el objeto y el fin de un tratado: a) si ha firmado el tratado o ha canjeado instrumentos que constituyen el tratado a reserva de ratificación, aceptación o aprobación, mientras no haya manifestado su intención de no llegar a ser parte en el tratado: o b) si ha manifestado su consentimiento en obligarse por el tratado, durante el periodo que preceda a la entrada en vigor del mismo y siempre que esta no se retarde indebidamente". Véase http://www.ordenjuridico.gob.mx/ TratInt/I1.pdf. 
serva. México está obligado a abstenerse de actos que frustren el objeto y fin de la Convención, entonces, su declaración interpretativa, que en realidad resulta ser una reserva, no es válida. Dicho de otra manera, México no está facultado para modificar el alcance temporal de la Convención sobre Imprescriptibilidad, toda vez que su objeto y fin es reafirmar un principio consuetudinario internacional: la imprescriptibilidad de los delitos de lesa humanidad, incluyendo el de genocidio. ${ }^{127}$ Las reservas que contradigan el objeto y fin de una Convención (por ejemplo, la Convención sobre Imprescriptibilidad), están prohibidas por el derecho de los tratados. Entonces, México al adherirse a esta convención hizo una declaración interpretativa sin valor alguno y no una reserva (prohibida si violenta el objeto y fin de la Convención misma). En este mismo orden de ideas, la SCJN derivó la discusión del verdadero problema (la aplicación de la Convención de Genocidio de 1948) por el pseudo problema de distinguir entre una declaración interpretativa y una reserva. Ahora bien, con relación a la aplicación retroactiva del principio de imprescriptibilidad, cabe señalar que existe una tensión entre la tradición penal y los derechos humanos (Becerra). Por otra parte, es relevante señalar que en la Convención Europea sobre Derechos Humanos, el delito también puede estar definido por el derecho internacional. ${ }^{128}$ Además, el concepto de retroactividad no es un concepto absoluto (Becerra). Para ilustrar este argumento, veamos una parte de la práctica internacional con relación a la sanción de delitos de lesa humanidad. Por ejemplo, en el caso de Klaus Barbie, la prescripción no es un concepto que pueda beneficiar un perse-

127 Becerra Ramírez, Manuel, op. cit., nota 15, p. 219. “... nos parece que lo que interpuso México no fue una reserva, sino una mera declaración interpretativa con los efectos que esto conlleva. Sin embargo, no era el asunto principal al que se debieron de abocar los ministros [de la SCJN], es un pseudo problema, pues la discusión está en la aplicación de la Convención sobre Genocidio de 1948 que de acuerdo con nuestro sistema constitucional es parte del derecho interno, y eso lo soslayaron los ministros".

128 “Artículo 7o. No hay pena sin ley. 1. Nadie podrá ser condenado por una acción y o una omisión que, en el momento en que haya sido cometida, no constituya una infracción según el Derecho nacional o internacional. Igualmente no podrá ser impuesta una pena más grave que la aplicable en el momento en que la infracción haya sido cometida. 2. El presente artículo no impedirá el juicio y el castigo de una persona culpable de una acción o de una omisión que, en el momento de su comisión, constituía delito según los principios generales del derecho reconocidos por las naciones civilizadas". Convenio Europeo para la Protección de los Derechos Humanos y Libertades Fundamentales. Véase http://www.derechos.org; Becerra Ramírez, Manuel, op. cit., nota 15. 
guido por delitos contra la humanidad. ${ }^{129}$ Dentro de la jerarquización producida en el ámbito internacional, la protección contra los delitos de lesa humanidad (incluye el delito de genocidio) ha cobrado un lugar especial. Por otra parte, el caso Pinochet enseña, por medio del juez

129 Sentencia del Tribunal Supremo sobre el caso Guatemala por genocidio, Equipo Nizkor, http://www.derechos.org/nizkor/guatemala/doc/gtmsent.html, consultada en septiembre de 2006. "La sentencia del Tribunal Supremo francés (Cour de Cassation) en el caso Klaus Barbie estableció que los crímenes contra la humanidad son imprescriptibles y pueden ser objeto de un procedimiento judicial en Francia cualquiera que haya sido la fecha o el lugar de comisión. Esta incriminación pertenece a un orden represivo internacional, al que Francia se ha adherido, y al que la noción de frontera le resulta ajena". Garcés, Joan, "Pinochet, ante la audiencia nacional y el derecho penal internacional", Equipo Nizkor, http://www.derechos.org/koaga/iii/5/garces.html, consultado en septiembre de 2006. Este autor señala que la definición del Estatuto del Tribunal de Nüremberg del crimen contra la humanidad (a. 6.c) ha sido aplicada por tribunales después de 1945, y cita los casos de Eichmann (Jerusalén, 1961); Menten (Países Bajos, 1982), Barbie (Francia 1983). Sobre éste último dice: “... en 1983, por el Tribunal Supremo de Francia en el caso Barbie, que fundamenta la aplicación del citado artículo 6.c) en los siguientes criterios (susceptibles de ser aplicables en España y Chile): a) esta inculpación pertenece a 'un orden represivo internacional al que le es fundamentalmente ajena la noción de frontera', b) la adhesión de Francia a este orden represivo, c) la consagración, por la resolución de 13.II.1946 de la Asamblea General de la ONU, de la definición de crímenes contra la humanidad que figura en el Estatuto del Tribunal de Nüremberg, d) la recomendación de las NN.UU. a los Estados, en esta resolución, de perseguir o extraditar a los autores de tales crímenes, e) la conformidad de tales textos con los artículos 15.2. del Pacto Internacional relativo a los Derechos Civiles y Políticos de 19.12.1966 (y al artículo 7.2 de la Convención Europea de Derechos del Hombre), que afirman que el principio de irretroactividad de las leyes penales no se opone a la persecución y condena de personas por hechos reputados como 'criminales según los principios generales del derecho reconocidos por la comunidad de las naciones'. Esta excepción —en el caso de que en propiedad lo fuera - a la irretroactividad de las leyes penales ha sido aplicada en la persecución penal contra una persona acusada de haber desviado un avión cuando éste hecho no era punible por el ius fori en el momento de haber sido cometido (Sri Lanka, Cr. of App., 28.5.1986, caso Ekanayake, I.1.R., 87, p. 298)"; Resolución del juez federal Gabriel R. Cavallo declarando la inconstitucionalidad y la nulidad insanable de los artículos 1o. de la Ley de Punto Final y 1o., 3o. y 4o. de la Ley de Obediencia Debida, en Equipo Nizkor, http://www.derechos.org/nizkor/arg/ley/juezcavallo03mar.html, consultada en septiembre de 2006. "Cabe mencionar también el proceso seguido en Francia contra Klaus Barbie, quien fue condenado por crímenes cometidos cuando el nombrado era jefe alemán de la Gestapo en Lyon. El Tribunal de Casación francés, en su sentencia del 20 de diciembre de 1985, 'dictaminó que los crímenes de lesa humanidad son imprescriptibles y que pueden ser objeto de un procedimiento judicial en Francia, cualesquiera que hayan sido la fecha y el lugar de su comisión"”. 
Nicholls, que los actos de tortura o secuestro no se justifican aunque hayan sido cometidos por un jefe de Estado.

En el ámbito interamericano, según la Corte IDH, la actuación del Estado no puede fundarse sobre el desprecio de la dignidad humana. ${ }^{130}$ El 24 de agosto de 2004, la Suprema Corte argentina determinó la imprescriptibilidad de los delitos de lesa humanidad, aduciendo que la Convención sobre Imprescriptibilidad solamente cristaliza el principio de la imprescriptibilidad de los delitos de lesa humanidad. Este principio posee un carácter ius cogens, luego entonces, no importa el tiempo en que dicha nación haya ratificado la citada Convención sobre Imprescriptibilidad, ya que sólo reafirma el principio mencionado (no lo pone en vigor, reafirma un principio vigente). Es decir, la Suprema Corte argentina enuncia (para el derecho interno argentino) lo que se sabe a nivel internacional: que los delitos de lesa humanidad no prescriben en virtud de su naturaleza. La misma Suprema Corte argentina fortalece su argumentación también con la jurisprudencia de la Corte IDH, en el sentido de que la prescripción de la acción penal no puede generar (válidamente) impunidad en los casos de presuntos violadores de derechos humanos. ${ }^{131}$

130 Becerra Ramírez, Manuel, op. cit., nota 15, p. 222.

131 "Corte Suprema de Justicia de la Nación Argentina, 24 de agosto de 2004. Recurso de Hecho en la Causa Arancibia Clavel, Enrique Lautaros/Homicidio Calificado y Asociación Ilícita y Otros", Diálogos Jurisprudenciales, IIDH-UNAM, Instituto de Investigaciones Jurídicas-Honrad Adenauer Stiftung, http://www.juridicas.unam.mx/pu blica/librev/rev/dialjur/cont/1/cnt/cnt13.pdf. "Sinopsis: La Suprema Corte de Justicia de la Nación Argentina emite una sentencia mediante la cual aborda la temática de la imprescriptibilidad de los crímenes de lesa humanidad. El imputado de la causa es condenado por su participación en homicidios, pero en el curso de las instancias procesales, es declarada prescrita la acción penal respecto del delito de asociación ilícita para delinquir. La Suprema Corte se encuentra con la necesidad de resolver si tal declaratoria de prescripción de la acción penal es congruente con el ordenamiento jurídico aplicable a la Argentina. En la construcción de su sentencia, la Suprema Corte inicia destacando que de conformidad con el derecho penal internacional, tanto por la vía del Estatuto de Roma de la Corte Penal Internacional, así como por la Convención para la Prevención y Sanción del Delito de Genocidio, la asociación para cometer algún delito de lesa humanidad es igualmente punible, llegando a considerarse que tal asociación es, al mismo tiempo, un delito de lesa humanidad. Luego de esa construcción jurisprudencial la Suprema Corte de Justicia de la Nación Argentina se vio en la necesidad de analizar si sobre tal delito existe prescripción de la acción penal, o si por el contrario la misma es imprescriptible. Para ello se dirige a la revisión de la Convención sobre la Imprescriptibilidad de los Crímenes de Guerra y de los Crímenes de Lesa Humanidad, cuya ratificación por el Estado argenti- 
Cabe mencionar que el Tribunal Penal Internacional para la ex $\mathrm{Yu}$ goslavia (TPIY) en una de sus sentencias ha declarado que el derecho a no sufrir tortura ni otros tratamientos crueles, inhumanos y degradantes es un "derecho absoluto que no admite derogación alguna" y que en este sentido la prohibición de la tortura es una norma de carácter ius cogens. ${ }^{132}$ Por su parte, cabe señalar que el artículo 14 de la Constitución mexicana, ${ }^{133}$ interpretado a contrario sensu, implica que una ley podrá

no sucede con posterioridad a los hechos analizados, y concluye que esa circunstancia no obsta para reconocer que con anterioridad a los hechos del caso, la comunidad internacional había construido una regla consuetudinaria, del ius cogens, por el que reconocía tal imprescriptibilidad, de manera que la ratificación de la indicada Convención no es más que la cristalización de la norma de imprescriptibilidad ya establecida. De esta manera, concluye que la acción de asociación para cometer delitos de lesa humanidad es un delito de lesa humanidad imprescriptible. En adición a ello, la Suprema Corte de la Nación Argentina retoma la jurisprudencia de la Corte Interamericana de Derechos Humanos en cuanto a que la prescripción de la acción penal no puede operar válidamente para generar impunidad en los casos de violaciones de derechos humanos, y concluye que darle validez a las normas de prescripción en estos casos sería una violación de la obligación del Estado argentino de garantizar los derechos humanos consagrados en la Convención Americana" (énfasis añadido).

132 The Prosecutor vs. Anto Furundzija, Case núm. IT-95-17/1-T. Judgement. 10 December 1998. Trial Chamber II (Judges Mumba [Presiding], Cassese and May), en http:// www.un.org/icty/Supplement/supple/furundzija.htm "International human rights law which, the Chamber explained, deals with State responsibility rather than individual criminal responsibility, bans torture both in armed conflict and in time of peace. The prohibition laid down in treaties, both general such as the International Covenant on Civil and Political Rights of 1966 (hereinafter "the ICCPR"), and specific such as the Convention Against Torture and other Cruel, Inhuman or Degrading Treatment or Punishment of 1984 (hereinafter "the Torture Convention"), is an absolute right which may never be derogated from. In this regard, the Trial Chamber referred to the fact that the prohibition of torture is a norm of jus cogens which is discussed below. By these human rights treaties, States have committed themselves to refrain from committing torture (through their agents), and to prohibit and punish this crime. With regard to the latter obligation, States have accepted the compulsory jurisdiction to investigate, prosecute and punish perpetrators". Cabe señalar que Anto Furundzija fue condenado a ocho años de prisión por cooperar en actos de tortura y otros actos inhumanos. No nos referiremos a si la CPIY fue constituida legalmente o si ha funcionado adecuadamente.

133 Constitución Política de los Estados Unidos Mexicanos, http://www.diputa dos.gob.mx/LeyesBiblio/index.htm "Artículo 14. A ninguna ley se dará efecto retroactivo en perjuicio de persona alguna. Nadie podrá ser privado de la libertad o de sus propiedades, posesiones o derechos, sino mediante juicio seguido ante los tribunales previamente establecidos, en el que se cumplan las formalidades esenciales del procedimiento y conforme a las leyes expedidas con anterioridad al hecho. En los juicios del orden criminal 
ser aplicada retroactivamente en beneficio de alguna persona. Cuando hablamos de los crímenes contra la humanidad, encontramos que existen el presunto responsable y la víctima o sus deudos. Además, "sería irracional e injusto prohibir la aplicación retroactiva en beneficio de un inculpado de crímenes de lesa humanidad descobijando de protección a la víctima o sus deudos". ${ }^{134}$ Esta argumentación también es defendida por el ministro Silva Meza de la SCJN mexicana en su proyecto del 23 de febrero de 2005. En tratándose de crímenes contra la humanidad, la aplicación del principio de no retroactividad implicaría la protección del inculpado (el presunto responsable). Es decir, argumentando la protección de una garantía constitucional (irretroactividad) en materia de crímenes contra la humanidad, se estaría fomentando la impunidad de los presuntos responsables de dichos crímenes.

En este mismo orden de ideas, si se aplica el principio de retroactividad a favor de la víctima o sus deudos, se dejarían a salvo los derechos del inculpado (presunto responsable) a defenderse judicialmente. El principio de la imprescriptibilidad de los crímenes contra la humanidad es un principio de carácter consuetudinario y la costumbre internacional también obliga a México — a través del artículo 38 del Estatuto de la CIJ-. Sobre esto, cabe recordar que en el Estatuto del Tribunal de Nüremberg ya se habla de la imprescriptibilidad de los crímenes contra la humanidad (1945). Cabe señalar que este principio fue adoptado por Francia en su legislación en 1946, señalando que si los delitos de lesa humanidad son imprescriptibles, es debido a su naturaleza (protección de los derechos humanos).

Durante el siglo XIX también se habló de la imprescriptibilidad de delitos graves (Francia 1808, Austria 1852). ${ }^{135}$ Esta tesis fue defendida por Beccaria (De los delitos y las penas, Italia, 1764) y Bentham. "Es posible afirmar que se ha constituido una opinio juris sobre la imprescriptibilidad de los crímenes de guerra". ${ }^{136}$

queda prohibido imponer, por simple analogía, y aún por mayoría de razón, pena alguna que no esté decretada por una ley exactamente aplicable al delito de que se trata. En los juicios del orden civil, la sentencia definitiva deberá ser conforme a la letra o a la interpretación jurídica de la ley, y a falta de ésta se fundará en los principios generales del derecho".

134 Becerra Ramírez, Manuel, op. cit., nota 15, p. 223.

135 Idem.

136 Ibidem, p. 226. 
Como ya hemos señalado, en el mencionado caso Klaus Barbie (Francia, 1984) sin dificultad alguna se declara que los crímenes contra la humanidad son imprescriptibles. Por su parte, la Convención Europea de 1974 declara también la imprescriptibilidad de estos crímenes. Entonces ¿puede el juez mexicano aplicar la costumbre internacional?, esto nos conduce al mal redactado artículo 133 de la Constitución mexicana sobre la recepción del derecho internacional. Este artículo 133 no impide al Estado mexicano sujetarse al derecho internacional (Becerra).

Por otro lado, el artículo 38 del Estatuto de la CIJ estipula que la costumbre es una de las fuentes del derecho internacional, y este artículo es obligatorio para el Estado mexicano. Es decir, la costumbre internacional obliga a México por medio de los artículos 38 del Estatuto de la CIJ (fuentes de derecho internacional) y 133 constitucional (recepción del derecho internacional). Resumiendo, la SCJN mexicana, al resolver el caso sobre "Los Halcones": 1. fue indiferente al derecho internacional al crear un pseudo problema (diferencia entre declaración interpretativa y reserva), y 2. el verdadero problema es aplicar una norma consuetudinaria de tipo ius cogens: la imprescriptibilidad de los delitos contra la humanidad, incluyendo el genocidio. ${ }^{137}$ El ministro Silva Meza emitió un voto particular en el Recurso de Apelación 1/2004-PS de la SCJN respecto al caso "Los Halcones". ${ }^{138}$ Señala que no se puede realizar reserva a la Convención sobre Genocidio en virtud de que es un tratado que versa sobre derechos humanos. ${ }^{139} \mathrm{El}$ derecho de los tratados establece que un Estado puede formular válidamente una reserva a un tratado internacional a menos que la misma sea incompatible con el objeto y fin del tratado. Por otra parte, el artículo 14 de la Constitución mexicana permite (a contrario sensu) aplicar retroactivamente una ley en beneficio de alguna

\section{Idem.}

138 Suprema Corte de Justicia de la Nación, Apelación 1/2004-PS, voto particular que formula el señor ministro Juan N. Silva Meza, www.scjn.gob.mx/transparencia/ InformacionOtorgada/Juridica/1aSala/2004/APELACION\%201-2004PRIMERA\%20SA LA.doc, consultado en julio de 2006.

139 Becerra Ramírez, Manuel, op. cit., nota 15, pp. 81-82, op. cit., "Si se considerara reserva, no podría ser respecto a la aplicación retroactiva de la Convención sobre la Imprescriptibilidad de los Crímenes de Guerra y de los Crímenes de Lesa Humanidad, además, tampoco podría recaer sobre la imprescriptibilidad de los crímenes a que se refiere dicho instrumento internacional, ya que precisamente esos son unos de sus objetivos y finalidades; establecer lo contrario, sería soslayar lo que establece el artículo 19, inciso c), de la Convención de Viena sobre el Derecho de los Tratados...". 
persona. Señala que la Convención sobre Imprescriptibilidad rescata el derecho consuetudinario, el cual es obligatorio para el orden jurídico mexicano. Analiza el delito internacional de genocidio, el cual tiene la finalidad de proteger la existencia de ciertos grupos humanos considerados estables. ${ }^{140}$ El ministro Silva Meza señala que la intención de destruir a un grupo nacional, étnico, racial o religioso se distingue del móvil para cometer el crimen de genocidio. Es decir, el móvil es irrelevante para determinar la existencia del genocidio. Igual que la resolución de la SCJN en el caso Cavallo, el ministro Silva Meza usa como sinónimos los términos de "étnico" y "lingüístico".

Al analizar diversos instrumentos internacionales, así como la doctrina internacionalista, el ministro Silva Meza explica que el genocidio es imprescriptible, cualquiera sea la fecha de cometido el delito. ${ }^{141}$ La SCJN no está obligada a respetar una reserva inválida a nivel internacional en relación con la Convención sobre Imprescriptibilidad y puede realizar su propia interpretación en virtud de su facultad constitucional de interpretar las leyes que emanen de la Constitución, una interpretación - expresa- "que sea acorde no sólo con los compromisos adquiridos por nuestro país a nivel internacional, sino a la naturaleza de las normas y principios esenciales a la vida civilizada que se materializan como ius cogens en los instrumentos internacionales".

Los Estados partes de la Convención sobre Imprescriptibilidad no han previsto limitación alguna en el tiempo de la misma, por el contrario:

Se aprecia que la aplicación a esta clase de crímenes de las normas de derecho interno relativas a la prescripción de los delitos ordinarios suscita grave preocupación en la opinión pública mundial, pues impide el enjuiciamiento y castigo de las personas responsables de esos crímenes; por ello, reconocieron necesario y oportuno afirmar, por medio de la Convención de referencia, el principio de la imprescriptibilidad de los crímenes de

140 El ministro JSM lo que hace es seguir la argumentación de la SCJN respecto del caso Cavallo, Suprema Corte de Justicia de la Nación, amparo en revisión 140/2002.

141 Suprema Corte de Justicia de la Nación, voto que formula el señor ministro Juan N. Silva Meza, en el Recurso de Apelación 1/2004-PS, "La referida Convención y otros instrumentos internacionales que abordan el tema sobre la interpretación de los tratados, como la Convención de Viena sobre el Derechos de los Tratados, conducen a la conclusión de que el delito de genocidio es imprescriptible, cualquiera que sea la fecha en que se haya cometido, esto es, el genocidio, per se, es imprescriptible...", consultado en noviembre de 2006. 
guerra y de los crímenes de lesa humanidad y asegurar su aplicación universal.

Es más, la imprescriptibilidad de los crímenes de guerra y lesa humanidad (incluso el de genocidio) es un principio de carácter ius cogens, en virtud de que lesionan la humanidad en su conjunto. Los bienes jurídicos protegidos por el tipo penal de genocidio son: 1. el derecho a la vida; 2 . el derecho a la integridad física de las personas; 3. el derecho a la libertad; 4. el derecho a la igualdad; y 5. el principio democrático. Silva Meza analiza el primero de ellos: el derecho a la vida, y de manera contundente expresa: "nos preguntamos a través de qué argumentos se podría establecer que la irretroactividad de la ley vale más que el derecho constitucional de protección a la vida y que la prohibición internacional de genocidio, que ya existían desde mil novecientos setenta y uno, olvidándonos ya de la Convención sobre Imprescriptibilidad". Además que la prohibición de genocidio "forma parte de los principios generales de derecho internacional, como norma de ius cogens, y por ende, existe como derechos vinculatorios desde antes de los hechos juzgados".

El ministro Silva Meza critica la resolución de la SCJN sobre el caso "Los Halcones", porque ésta argumenta que siempre deben prevalecer los bienes individuales sobre los colectivos, apreciación que "parte de un entendimiento liberal de los derechos fundamentales, cuyo fundamento teórico está superado" y añade que "las principales tendencias académicas, por el contrario, sustentan que los derechos deben contribuir a la paz, a la igualdad, al aseguramiento de la democracia y a la protección de los más débiles", siendo los más débiles, en el delito internacional de genocidio, aquellos grupos aplastados en sus derechos por un régimen estatal hegemónico, y concluye que "la defensa de la prescriptibilidad del genocidio, contenida en la ejecutoria, tiende a fomentar regímenes totalitarios". En virtud de lo anterior, opina (en su voto particular), que la acción penal respecto del delito de genocidio no ha prescrito. Por esto podemos decir que el ministro Silva Meza es el ministro internacionalista de la SCJN y el que está a la vanguardia del derecho internacional dentro de la misma. 


\section{SUJECIÓN A PROCESO DE LUIS ECHEVERRÍA POR GENOCIDIO}

El 29 de noviembre de 2006, el magistrado del Segundo Tribunal Unitario en Materia Penal del Primer Circuito (magistrado Ricardo Paredes Calderón) resolvió la apelación promovida por el Ministerio Público Federal en contra del auto de del 8 de julio de 2006 del juez decimoquinto de Distrito de Procesos Penales Federales en el Distrito Federal (juez de Distrito), en la causa penal 78/2005-I que se instauró contra Echeverría por su probable responsabilidad en la comisión del delito de genocidio, previsto y sancionado por el artículo 149 bis del Código Penal Federal vigente el 2 de octubre de $1968 .{ }^{142} \mathrm{El}$ auto revocado establece lo siguiente: 1. la prescripción de la acción penal ejercida contra Echeverría por su probable responsabilidad en la comisión del delito de genocidio (causa penal 78/2005-I). 2. el sobreseimiento de la causa penal (78/2005-I). 3. que resulta innecesario abordar el estudio del cuerpo del delito de genocidio, así como la probable responsabilidad de Echeverría en la comisión genocidio; 4. se ordena remitir copia de esta resolución al director del Reclusorio Preventivo Varonil Sur de la Ciudad de México y al titular de la Agencia Federal de Investigación, para su conocimiento y efectos legales a que haya lugar, así como para que este último ordene a quien corresponda se retiren de manera inmediata las medidas de seguridad necesarias que se implementaron para la custodia permanente de Echeverría. Se giraron copias de citado auto al Ministerio Público Federal y al procurador general de la República.

El magistrado Paredes Calderón deduce del auto citado, que "el indiciado de mérito intervino como concepcionista, preparador y ejecutor, con pleno conocimiento del carácter ilícito de su actuar, en la realización del ilícito que se le imputa" y que "por ello es congruente considerar a" Echeverría como "probable responsable en la comisión del delito de genocidio, previsto y sancionado por el artículo 149 bis del Código Penal para el Distrito y Territorios Federales en Materia Federal, vigente en" 1968 "en el entendido de que el requisito que el presentado apartado se

142 Esta información fue tomada del periódico El Universal, el cual en su portal de Internet publicó una parte de la resolución del magistrado Ricardo Paredes Calderón decretando la formal prisión de Echeverría por su probable responsabilidad del delito de genocidio. Véase http://videos.eluniversal.com.mx/echeverria.pdf, consultado en junio de 2008 . 
tuvo por cumplido, fue solamente la concurrencia de datos suficientes eficaces, para considerar viable al menos, una razonable deducción en los hechos de una persona, que deberá ser materia de plena demostración en una ulterior etapa procesal preliminar, y por lo cual debe ser llamado a responder en tales términos, por los cargos que se le atribuyen". ${ }^{143}$

El magistrado Paredes Calderón considera acreditados los elementos del cuerpo del delito de genocidio, por lo que: 1. Ordena auto de formal prisión en contra de Echeverría, y que el procedimiento se siga de forma ordinaria. 2. Expresa que no resulta procedente suspender al procesado en el ejercicio de sus derechos políticos. 3. Ordena que se identifique al inculpado (obligación de conocer plenamente la identidad y demás datos personales y características del inculpado) y que se sujete a procedimiento al inculpado y se decrete orden de reaprehensión en contra de Echeverría conforme al artículo 195, segundo párrafo del Código Federal de Procedimientos Penales (se transcribe la resolución al agente del Ministerio Público Federal para que ordene su ejecución) y se ponga "sin demora alguna al aprehendido a disposición del Juzgado Decimoquinto de Distrito de Procesos Penales Federales en el Distrito Federal. 4. En virtud del estado precario de salud del inculpado se ordena que la prisión preventiva se lleve a cabo en el domicilio del propio indiciado, bajo las medidas de seguridad que procedan de acuerdo con la representación social. 5. Ordena la suspensión del procedimiento "hasta que el inculpado sea reaprehendido y puesto a disposición del juez de la causa". 6 . En este sentido, se revoca la resolución apelada (auto del 8 de julio de 2006, juez de Distrito, expediente 78/2005-I), abierto con motivo de la acción penal en contra de Echeverría por su probable responsabilidad en la comisión del delito de genocidio. Esta resolución del magistrado Calderón, del 29 de noviembre de 2006, representa "la primera decisión en la historia del país de iniciar un juicio a un ex presidente por los crímenes del pasado"; es una "resolución tomada hace menos de cuatro meses" y que "anuló a su vez el fallo del Juzgado Décimo Quinto de Distrito en Materia de Procesos Penales Federales, quien en julio pasado había liberado a Echeve- 
rría al considerar que el delito de genocidio prescribe a los 30 años, y por tanto la acusación dejó de tener vigencia". ${ }^{144}$

El 14 de marzo de 2007, la defensa de Echeverría interpone juicio de garantías (amparo) en contra del auto de formal prisión ordenado por el magistrado Paredes Calderón el 29 de noviembre de 2006 por la probable responsabilidad del delito de genocidio. ${ }^{145} \mathrm{El}$ asunto quedó radicado en el Tercer Tribunal Unitario.

La defensa argumentó lo siguiente: 1. la prescripción de la acción penal por el delito de genocidio; 2. negaron que los hechos ocurridos el 2 de octubre de 1968 representen una política de exterminio por parte del Estado mexicano; y 3. que Echeverría no estaba al frente del operativo policiaco ni del Batallón Olimpia, al que se le adjudica la autoría de la matanza en Tlatelolco. El 20 de marzo de 2007, el magistrado Jesús Guadalupe Luna Altamirano, titular del Tercer Tribunal Unitario en Materia Penal del Primer Circuito, concedió la suspensión en contra del auto de formal prisión ordenado por el magistrado Paredes Calderón, así como contra la realización de los estudios criminológicos y de la ficha signalética. ${ }^{146}$ El Quinto Tribunal Colegiado en Materia Penal del Distrito Federal, resolverá en definitiva el juicio de amparo que enfrenta Echeverría. Los magistrados del Tribunal, Manuel Bárcena, Rosa Guadalupe Malvina y María Eugenia Martínez, quienes revisarán el juicio de amparo contra el auto de formal prisión que enfrenta Echeverría, no desean que el Canal Judicial transmita la sesión en la cual discutirán si procede o no el amparo. Se rumorea que:

El proyecto de resolución elaborado por la ponencia del magistrado Bárcena propone convalidar el amparo en favor de Echeverría, es decir, sugiere confirmar el argumento de Luna Altamirano respecto de que sí ocurrió un genocidio hace 38 años en Tlatelolco, pero que los recursos jurídicos ofrecidos por la PGR para desvirtuar el fallo del magistrado unitario fueron "inoperantes e insuficientes" para acreditar que el ex presidente debe ser

144 Otero, Silvia, "PGR recibe un nuevo revés; otorga juez protección a Echeverría para evitar cárcel”, El Universal, http://www.eluniversal.com.mx/nacion/149470.html, junio de 2008.

145 Otero, Silvia, "Echeverría la quiere librar con amparo", El Universal, http://www. eluniversal.com.mx/grafico/64249.html, consultado en junio de 2008.

146 Otero, Silvia, "Congelan temporalmente proceso contra Echeverría", El Universal, http://www.eluniversal.com.mx/notas/413490.html, consultado en Junio de 2008. 
juzgado por un juez de procesos penales federales como probable responsable de la matanza de estudiantes registrada en la Plaza de las Tres Culturas. ${ }^{147}$

Esta resolución será importante para conocer la versión "oficial" de este caso. En el futuro, quizá será necesario crear una "comisión de la verdad" que determine la "verdad histórica" de los hechos ocurridos en Tlatelolco en 1968 y los del 10 de junio de 1971, para que las futuras generaciones conozcan los hechos ocurridos y no se vuelvan a repetir.

\section{CONCLUSIONES}

1. El tipo penal de genocidio en México es un tipo penal base mediante el cual también deben sancionarse las conductas tipificadas como "crímenes contra la humanidad"; esto es así, en virtud de que la legislación secundaria mexicana es omisa en tipificar los crímenes contra la humanidad.

2. La obligación de prevenir y sancionar el genocidio es una norma consuetudinaria de carácter ius cogens, lo cual implica que el genocidio es sancionable, no importa el tiempo en que se haya cometido, es decir, la obligación de prevenir y sancionar el genocidio es imprescriptible.

3. La imprescriptibilidad de los crímenes de lesa humanidad y genocidio es un principio superior al de irretroactividad de los tratados y de la legislación secundaria en los ordenamientos nacionales de los Estados.

4. No es impedimento para el juez mexicano sancionar como genocidio conductas que doctrinalmente tipificarían más bien crimen de lesa humanidad; esto es así, toda vez que el genocidio originalmente fue definido coma una especie de los crímenes contra la humanidad en el Tribunal de Nüremberg desde 1945 y posteriormente se definiría autónomamente en la Convención de Genocidio, la cual, a su vez, es obligatoria para todos los Estados por tener carácter de norma ius cogens y cualquier reserva que se oponga a su objeto y fin es nula de pleno derecho. Esto redundaría en beneficio de la expansión de los derechos humanos, ya que la jurisprudencia es una de las actividades del derecho que debe dar con-

147 Méndez, Alfredo, "Magistrados desean discutir el caso Echeverría en lo oscurito", La Jornada, 11 de junio de 2008, http://www.jornada.unam.mx/2008/06/11/index. php? section $=$ politica\&article $=019$ n2pol\&partner $=r s s$, consultado en junio de 2008. 
tenido e identificar las normas de carácter ius cogens en la práctica de los Estados, como lo es la obligación de prevenir y sancionar el genocidio y los crímenes contra la humanidad.

5. Para mayor seguridad jurídica de los individuos en el territorio nacional, debe tipificarse el crimen de lesa humanidad en el Código Penal Federal y reformarse la Constitución federal para reconocer (no para "crear") la imprescriptibilidad de los crímenes de lesa humanidad y genocidio.

6. Para beneficio de las generaciones futuras será necesario crear también una "comisión de la verdad" que esclarezca la "verdad histórica" de al menos los hechos ocurridos en México en 1968 y 1971. 